\title{
ANNUAL STATUS REPORT on the Uranium Mill Tailings Remedial Action Program
}

December 1989

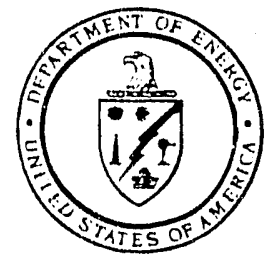

U.S. Department of Energy

Office of Environmental Restoration and Waste Management Washington, D.C. 20545

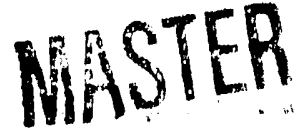




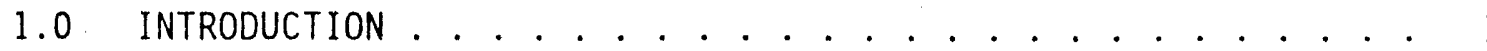

2.0 PROGRAM STATUS .................. 3

2.1 Vicinity properties. .............. 3

2.2 Certification and licensing. . . . . . . . . . . 3

2.3 Acquisition of Real Estate . . . . . . . . . 3

2.4 NEPA Documents . . . . . . . . . . . . . . . . 4

2.5 Quality Assurance and Health and Safety. . . . . . . . 4

2.6 Surveillance arid maintenance .......... . 4

2.7 Program planning ............ . 5

2.7.1 Project planning ............ 5

2.7.2 Projert procurement. . . . . . . . . . 5

2.8 Remedial action. . . . . . . . . . . . 6

2.y Puilic participation ........... 6

2.10 Cost Reduction/Productivity Improvement Program. . . . 7

2.11 Uiher Federal agency activities. . . . . . . . . . . 7

2.11.1 U.S. Department of the Interior (DOI). . . . . 7

2.11 .2 U.S. Department of Justice (DOJ)...... . 8

2.11 .3 U.S. Nuclear Regulatory Commission...... . 9

2.11.4 U.S. Environmental Protection Agency . . . . . . 10

2.12 State and Indian tribe activities. . . . . . . . 10

2.13 Status of designated sites ............ 11

2.13.1 Ambrosia Lake, New Mexico. . . . . . . . . 11

2.13.2 Belfield and Bowman, North Dakota........ 11

2.13.3 Canonsburg, Pennsylvania .......... 11

2.13 .4 Durango, Colorado. ............. 11

2.13.5 Edgemont, South Dakota ........... . 12

2.13.6 Falls City, Texas. . . . . . . . . . . 12

2.13.7 Grand Junction, Colorado . . . . . . . . . . 12

2.13.8 Green River, Utah. . . . . . . . . . . . . 13

2.13.9 Gunnison, Colorado . . . . . . . . . . . 13

2.13.10 Lakeview, Oregon . . . . . . . . . . . . 14

2.13.11 Lowman, Idaho. . . . . . . . . . . . . . . 14

2.13.12 Maybe11, Colorado. . . . . . . . . . . . 14

2.13 .13 Mexican Hat, Utah. . . . . . . . . . . . . 14

2.13.14 Monument Valley, Arizona . . ......... . 15

2.13.15 Naturita, Colorado . . . . . . . . . 15

2.13.16 01d and New Rifle, Colorado......... 15

2.13.17 Riverton, Wyoming. . . . . . . . . . . . . 16

2.13.19 Shiprock, New Mexico. . . . . . . . . . . . . 16

2.13 .20 S7ick Rock, Colorado . . . . . . . . . . . 17

2.13 .21 Spook, Wyoming ........... . . 17

2.13 .22 Tuba City, Arizona . . . . . . . . . 17

Appendix A, Program Funding Appendix $B$, Figures and Tables

Appendix $C$, Comments from States and Tribes

Appendix D, Photographs of Remedial Action 


\subsection{INTRODUCTION}

This eleventh annual status report summarizes activities of the Iranium Mill Tailings Remedial Action (UMTRA) Project undertaken during Fiscal Year (FY) 1989 by the U.S. Department of Energy (DOE) and other agencies. Project goals for FY 1990 are also presented. An annual report of this type was a statutory requirement through January 1, 1986, pursuant to tr- Uranium Mill Tailings Radiation Control Act (UMTRCA) of 1978 , Public Law (PL) 95-604. The DOE will continue to submit an annual report through project completion in order to inform the public of yearly project status.

Title I of the UMTRCA authorizes the DOE, in cooperation with affected states and Indian tribes within whose boundaries designated uranium processing sites are located, to provide a program of assessment and remedial action at such sites. The purpose of the remedial action is to stabilize and control the tailings and other residual radioactive materials located on the inactive uranium processing sites in a safe and environmentally sound manner and to minimize or eliminate potential radiation health hazards. Commercial and residential properties in the vicinity of designated processing sites that are contaminated with material from the sites, herein referred to as "vicinity properties, "are also eligible for remedial action. Included in the UMTRA Project are 24 inactive uranium processing sites and associated vicinity properties located in 10 states, and the vicinity properties associated with Edgemont, South Dakota, an inactive uranium mill currently owned by the Tennessee Valley Authority (TVA) (see Figure B.1, Appendix B).

Summarized below are the UMTRA Project FY 1989 major accomplishments and FY 1990 goals.

\section{FY 1989 Project Accomplishments:}

- Completed the following processing site remedial actions: 98 percent of Lakeview, OR; 100 percent of Salt Lake City, UT; 100 percent UMTRA portion of Spook, WY; 88 percent of Rivertcn, WY; 71 percent of Tuba City, AZ; 62 percent of Green River, UT; 63 percent of Durango CO; 31 percent of Mexican Hat, UT, and Monument Valley, AL; 14 percent of Ambrosia Lake, NM; 10 percent of Rifle, CO; eight percent of Monument Valley, AZ; and 10 percent of Grand Junction, CO.

- Initiated remedial action contracts on 737 vicinity properties for eight designated sites, and completed inclusion decision activities on a total of 340 vicinity properties. Significant progress was made on completion of remedial action of complex commercial properties in Durango, Co.

- Completed National Environmental Policy Act (NEPA) ciocuments for Mexican Hat, UT; Monument Valley, AZ; and Spook, WY. 
- Comnleted Remedial Action Plans (RAPs) for Mexican Hat, UT, and Monument Valley, AZ (modification); Rifle, CO; Tuba City, AZ; and Spook, WY. Prepared the draft RAP for Maybe11, CO.

- Revised Project documentation to include the Project Quality Assurance Plan, Project Environmental, Health, and Safety Manual, and Project Document Control System Manual. Completed the Project Remedial Action Planning and Disposal Cell Design to comply with the proposed E.PA Standards and the Final Response to Standards for Remedial Actions at Inactive Uranium Processing Sites. Prepared UMTRA portion of the DOE Environmental Restoration and Waste Management Five Year Plan.

\section{FY 1990 Project Goals:}

- Initiate processing site remedial action at Grand Junction, CO (Phase II); Ambrosia Lake, NM (Phase II); and Rifle, CO (Phase II), as funding allows. Continue remedial action at Durango, CO, and Mexican Hat, UT, and Monument Valley, AZ. Complete remedial action at Green River, UT; Tuba City, $A Z$; Riverton, WY; and Lakeview, OR.

- Complete NEPA documents for all remaining sites, except Gunnison, Maybe 11, and Slick Rock, CO; and complete site design and RAPs for all sites except Lowman, ID; Gunnison, CO; and Slick Rock, CO.

- Issue project policy statements regarding post-UMTRA disposal of contaminated materials and state funding shortfalls.

- Initiate procurement for technical support and groundwater restoration management contractor and revise the groundwater restoration budget and milestone plan.

- Complete U.S. Nuclear Regulatory Commission (NRC) certification of the Canonsburg, PA, and Shiprock, NM, sites; and transfer the Canonsburg site to the DOE long-term surveillance and maintenance program.

- Complete inclusion surveys and inclusion/exclusion recommendations for approximately 348 vicinity properties.

a Complete engineering for 514 vicinity properties, initiate remedial actions at 705 properties, issue completion reports for 701 properties, and certify 700 properties. 
- Completed Remedial Action Plaris (RAPS) for Mexican Hat, UT, and Monument Valley, $A Z$ (modification); Rifle, CO; Tuba City, $A Z$; and Spook, WY. Prepared the draft RAP for Maybe11, CO.

- Revised Project documentation to include the Project Quality Assurance Plan, Project Environmental, Health, and Safety Manual, and Project Document Control System Manual. Completed the Project. Remedial Action Planning and Disposal Cell Design to comply with the proposed EPA Standards and the Final Response to Standards for Remedial Actions at Inactive Uranium Processing Sites. Prepared UMTRA portion of the DOE Environmental Restoration and Waste Management Five Year Plan.

\section{FY 1990 Project Goals:}

- Initiate processing site remedial action at Grand Junction, Co (Phase II); Ambrosia Lake, NM (Phase II); and Rifle, CO (Phase II), as funding allows. Continue remedial action at Durango, $\mathrm{CO}$, and Mexican Hat, UT, and Monument Valley, AZ. Complete remedial action at Green River, UT; Tuba City, AZ; Riverton, WY; and Lakeview, OR.

- Complete NEPA documents for all remaining sites, except Gunnison, Maybel1, and Slick Rock, CO; and complete site design and RAPs for all sites except Lowman, ID; Gunnison, CO; and Slick Rock, CO.

- Issue project policy statements regarding post-UMTRA disposal of contaminated materials and state funding shortfalls.

- Initiate procurement for technical support and groundwater restoration management contractor and revise the groundwater restoration budget and milestone plan.

- Complete U.S. Nuclear Regulatory Commission (NRC) certification of the Canonsburg, PA, and Shiprock, NM, sites; and transfer the Canonsburg site to the DOE long-term surveillance and maintenance program.

- Complete inclusion surveys and inclusion/exclusion recommendations for approximately 348 vicinity properties.

- Complete engineering for 514 vicinity properties, initiate remedial actions at 705 properties, issue completion reports for 701 properties, and certify 700 properties. 


\subsection{PROGRAM STATUS}

Progress made during FY 1989, present status, and plans for FY 1990 are described below and are summarized in Tables B.1, B.2, and B.3 of Appendix B.

\subsection{VICINITY PROPERTIES}

The number of inclusion surveys for vicinity properties decreased in 1989 as the number of properties remaining for survey decreased. Over 1000 properties had inclusion/exclusion recommendations submitted this past year. The engineering was completed for 697 properties, 782 remedial actions were documented in completion reports, and 795 properties were certified. In addition to significant progress in survey, engineering, and remedial action activities, a comprehensive vicinity property programmatic review was completed. This review identified suggestions to provide more consistent and streamlined processes to survey, remediate, and verify vicinity properties on the UMTRA Project. A summary of vicinity property activities by site during FY 1989 and to date is presented in Table B.3 of Appendix B.

\subsection{CERTIFICATION AND LICENSING}

No sites were certified in FY 1989. In FY 1990 the NRC is expected to concur that remedial actions at Canonsburg and Burre11, PA, and Shiprock, NM, are in compliance with the applicable regulatory requirements.

The NRC has revised its policy regarding certification of individual UMTRA Project sites. The policy now provides for NRC concurrence that remedial action at completed site meets design specifications. The site will then be brought under a general license with the NRC's approval of the site Surveillance and Maintenance (S\&M) Plan, based on the provisions of the Advanced Notice of Proposed Rulemaking for long-term custodial care of the UMTRA Project sites.

\subsection{ACQUISITION OF REAL ESTATE}

New Mexico: The state owns surface rights on Tract $A$ of the Ambrosia Lake site and is in the process of finalizing the acquisition of the subsurface rights from Hecla Mining Company. The state also has authority from the DOE to proceed with the acquisition of a restrictive easement on Tract $B$.

Wyoming: The state has acquired the necessary 1 ands for the Riverton site and the surface rights for the Spook site. A request to transfer subsurface jurisdiction from the Bureau of Land Management (BLM) to the DOE at the Spook site is currently in process. 
Texas: The mill site surface area at the falls city site is in the process of being donated to the state by Solution Engineering, Inc. Appraisals for the additional lands required for the disposal cell area are complete and are under review, and the subsurface appraisal has been advertised.

Colorado: All lands for the Grand Junction disposal site have been acquired and the permanent transfer of jurisdiction of BLM lands is currently in process. All lands related to the mill sites at Rifle have been acquired. Land for the disposal area will be transferred from the BLM to the DOE. Acquisition of the Durango disposal site is completed. Acquisition and transfer of Federal land jurisdiction is required for the remaining sites in colorado.

Acquisition is completed for all sites in Oregon, Pennsylvania, and Utah, and is underway for sites in Idaho and North Dakota.

\subsection{NEPA DOCUMENTS}

The NEPA documents prepared in FY 1989 included Monument Valley, $A Z$, final Environmental Assessment (EA) and Finding of No Significant Impact (FONSI); Rifle, CO, preliminary final Environmental Impact Statement (EIS); Spook, WY, final EA and FONSI; and Belfielu/Bowman, ND, draft EA.

The NEPA documents scheduled for FY 1990 include final EAs and FONSIs for the following sites: Falls City, TX; Gunnison, CO; Belfield and Bowman, ND; Lowman, ID; Slick. Rock, Naturit;, and Maybe11, CO; and the final EIS and ROD for Rifle, CO. Draft EAs will also be prepared for Gunnison, Maybe11, and Slick Rock, CO.

\subsection{QUALITY ASSURANCE AND HEALTH AND SAFETY}

A significant factor in the effective implementation of the UMTRA Project Quality Assurance (QA) and Health and Safety (H\&S) programs is the performance of audit and surveillance activities to assess the status and effectiveness of these programs. In FY 1989, independent review teams from DOE/LMTRA and the Technical Assistance Contractor (TAC) conducted 24 programmatic QA audits/in-process QA surveillances of project contractors and participating organizations. Nine environmental, health, and safety audits were performed and seven H\&S site visits or surveillances were performed at project remedial action sites during the 1989 remedial action season. In addition, a special transportation safety review/inspection was performed at Durango.

\subsection{SURVEILLANCE AND MAINTENANCE}

The revised NRC policy for certification requires that draft S\&M Plans for sites be submitted to the NRC for review approximately six months prior to completion of remedial action, and final S\&M Plans be submitted to the NIRC for approval within six months after 
completion of remedial action. Upon completion of site, certification by the NRC, the DOE Grand Junction Project office (GJPO) will be responsible for conducting long-term S\&M activities. Short-term S\&M was conducted by the UMTRA Project during FY 1989 on those sites which have completed remedial action. It is anticipated that NRC certified sites wi1l, be passed to the GJPO starting in FY 1991 .

\subsection{PROGRAM PLANNING}

\subsubsection{Project planning}

The revised project plan, project management plan, and project schedule and cost estimate report were published with a projected total estimated cost (TEC) of $\$ 1,139.1$ million. This revised TEC was estimated for submission with the FY 1991 Congressional budget request (see Table A.1, Appendix A). The current schedule for completion of the Project in September of 1994 is provided in Appendix B (Figure B.2).

Management plans were developed by a 11 contractors and submitted to the DOE. The plans provide detailed accounts of the methods the contractors will use to meet their objectives for the remainder of the Project.

\subsubsection{Project procurement}

Jacobs Engineering Group Inc. (JEG), the principal TAC, is continuing technical performance under contract Task Agreement No. 5 (TA5), which is scheduled to end September 30, 1990. The TAC contract is provisionally funded on a monthly basis until such time as TA 5 can be negotiated between DOE and JEG. Negotiations are tentatively scheduled to be completed in February 1990. The TAC is responsible for providing technical and management support to the UMTRA Project including planning and design development; NEPA document preparation; environmental, health, and safety procedures; quality assurance; and initial surveillance and maintenance of disposal sites. The TAC also acts as the integrating contractor for project-wide management control and provides radon monitoring of the processing sites before and after remedial action.

Tasks were added to the contract with MK-Ferguson Company (MK-F), the principal Remedial Action Contractor (RAC) for the UMTRA Project. The RAC is responsible for the engineering and design of approved remedial actions, construction management, and accomplishment of remedial actions through the use of competitively awarded fixed-price subcontracts for all mill sites (except at Salt Lake City, which was managed by the state of Utah) and all vicinity properties (except at Grand Junction and Edgemont, which are managed by the DOE (GJPO). 
The GJPO prime contractor, United Nuclear Corporation Geotech (UNC-G), is responsible for engineering design and remedial actions for vicinity properties at Grand Junction and Edgemont, radiological data acquisition for site characterization, and operation of the Technical Measurement Center.

The other major project contractor is Oak Ridge Nalional Laboratory (ORNL), which provides vicinity property inclusion surveys and independent property verification.

\subsection{REMEDIAL ACTION}

Site remedial action completion in FY 1989 included Salt Lake city, UT, and Spook, WY. During the same period, remedial action was initiated at Spook, WY, Green River, UT, and Monument Valley, $A Z$. Phase I remediai action was initiated and completed at Ambrosia Lake, NM, and at Grand Junction and Rifle, Co.

Ongoing remedial action construction activities continued at Lakeview, OR; Durango, CO; Riverton, WY; and Tuba City, AZ. Remedial action starts in FY 1990 will include Grand Junction, CO (Phase II); Ambrosia Lake, NM (Phase II); and Rifle, Co (Phase II), as funding availability permits.

\subsection{PUBLIC PARTICIPATION}

Fifteen public information meetings were held during $F Y 1989$, as follows: Durango (1), Falls City (2), Grand Junction (3), Gunnison (1), Lowman (1), Mexican Hat (1), Naturita (1), Rifle (1), Slick Rock (2), and Tuba City (2). Topics at these information meetings ranged from status reports on site activities and project progress to groundwater characterization results and H\&S programs.

Much of the public participation activities in FY 1989 were performed in support of the Grand Junction site. In addition to the public information meetings noted above, three public hearings were held in Grand Junction. Two were held in late January " "early February to facilitate public input into the Mesa County Conditional Use Permit review process. The third, which was held in late March, provided the Mesa County Board of Commissioners a final opportunity to review project plans before voting to approve the permit. Attendance at the three hearings totalled more than 600 people. Other Public Information/Public Participation Program activities in Grand Junction included briefings and site tours for local elected officials, Congressional representatives, and the media; a December 7 , 1988, news conference to announce the award of a remedial action subcontract; and the establishment of public information repositories at the Mesa County Public Library and the Whitewater General Store.

During FY 1989, groundbreaking ceremonies were held at two sites. On November 2? approximately 40 people attended the Green 
River groundbreaking, including representatives of Utah Governor Norman Bangerter, the Utah Congressional delegation, the Utah legislature, Grand County, Emery County, and the City of Green River, and Project personnel. Groundbreaking activities were conducted on April 20 at Spook, and included remarks by representatives of the DOE, the State of Wyoming, and Converse county.

Other activities in FY 1989 included coordination and preparation of briefing materials for Project presentations at citizens task force meetings in Project communities; development of economic impact analyses for state Project participants; production of the FY 1988 Project video; coordination and training of Project staff for media briefings, radio talk show appearances, and television interviews; development and updating of written information materials for public distribution to maintain awareness of current Project progress and activities; and coordination and preparation for the Lakeview closing ceremony and the 1989 DOE/States/Tribes Project Coordination Meeting, both of which occurred in early FY 1990.

\subsection{COST REDUCTION/PRODUCTIVITY IMPROVEMENT PROGRAM}

The UMTRA Project's cost Reduction/Productivity Improvement Program, completing its second year of operation in FY 1989, exceeded its goal of $\$ 7.6$ million with a record net benefit of $\$ 11.2$ million. This was accomplished through a 40 percent participation rate from all project participants and contractors. Participation goals for FY 1990 are for 50 percent participation with a net benefit of $\$ 5$ million.

\subsection{OTHER FEDERAL AGENCY ACTIVITIES}

Coordination with participating Federal agencies continued and meetings were conducted to exchange information and resolve problems. The following are contributions to this report from Federal agencies cooperating with the DOE on the Project.

\subsection{1 .1 U.S. Department of the Interior (DOI)}

The DOI is conducting a long-term study concerning the geochemical aspects of uranium mill tailings in progress within the Water Resource Division of the United States Geological survey (USGS). The purpose of this study is to identify the geochemical forms of radionuclides and to determine the mobilization mechanisms in the environment. The Puerco and Little Colorado Rivers Study conducted by the Arizona District of USGS is also continuing. This study involves an assessment of the transport into the environment of radionuclides and trace elements that originated from uranium mining waste. 
The DOI has also reviewed and provided comments on the environmental analysis for remedial action at the Monument Valley uranium mill tailing site in Aparhe County, Arizona.

\subsection{1 .2 U.S. Department of Justice (DOJ)}

The Land and Natural Resources Division of the Dou has been designated by the Attorney General to perform staff work necessary to conduct the studies under section 115(b) of PL95-604 (UMTRCA) to determine the identity and legal responsibility of any person who owned, operated, or controlled any site designated under the UMTRCA. The Attorney General's Section 115 (b) study with respect to the Salt Lake City site is still pending. A factual summary of available DOE and NRC documentation was completed by an outside contractor during the current fiscal year, and was in the process of being submitted to the DOE and NRC for review and comment as to accuracy at year's end.

As previously renorted, the case of Dunn, et al. $V$. United States, et al., Civil Action No. 82-04.37 (W.D.Pa.), which had sought injunctive relief concerning remedial action at the Canonsbury, PA, site, was resolved on the merits by a Consent Judgement entered May 5, 1984. This litigation continued, however, based on the government's opposition to an award of attorney's fees to the plaintiffs under the Equal Access to Justice Act (EAJA) 42 USC 1988. The District Court initially determined the plaintiff's EAJA fee application had not been filed in a timely manner, and that the court therefore lacked authority to award fees. A divided panel of the U.S. Court of Appeals for the Third Circuit reversed the decision, however, and remanded the case at the end of 1985 for further proceedings. On remand, the District court received evidence and briefing on the plaintiffs' entitlement to attorney's fees, and awarded the plaintiffs' attorney's fees and costs in the total amolint of $\$ 144,590.65$.

On March 23, 1988, this award was vacated by the court of Appeals, which held that the District Court's finding that the plaintiffs had prevailed was clearly erroneous and unsupported by the evidence. The court also concluded that the plaintiffs should have a final opportunity to produce evidence in support of their status as prevailing parties, and remanded the case for further proceedings. Pursuant to that remand the District Court, on May 25, 1988, held an evidentiary hearing on the issue of the plaintiffs' status as prevailing parties. Thereafter, on February 16, 1989, the District Court entered its Opinion and order, disallowing in its entirety the plaintiffs application for an award of attorney's fees and costs totaling $\$ 204,894.56$. The District Court based its decision on the government's argument that the plaintiffs' ware not "prevailing parties" and held, in the alternative, that 
the government's position in the prelitigation and litigation stages of the controversy had been substantially justified. No appeal was prosecuted by the plaintiffs from the District Court!s decision.

As previously reported, the case of Hecla Mining Co. V. United States, Civil Action No. 87-M-1638 (D. Colo.), a mandamus action, seeking to compel the Secretary of Energy to perform alleged ministerial duties under UMTRCA to proceed with remedial action at the designated inactive mill site located near Naturita, $\mathrm{CO}$, and to designate an alleged "vicinity property" owned by Hecla for inclusion in the UMTRA Project, was filed on October 29, 1987. On October 10, 1988, the District Court entered an Order granting the government's motion for summary judgement. Judgement was entered dismissing all claims for relief asserted by Hecla Mining Company, on October 11, 1989. On November 7, 1988, the District Court, sua sponte, denied Hecla Mining's motion for an award of costs and attorney's fees totaling $\$ 81,946.29$ under EAJA on the ground that Hecla Mining had not prevailed in the litigation. Hecla Mining filed its Notice of Appeal on December 19, 1988. The case has been fully briefed, and at the close of FY 1989 was pending before the U.S. Court of Appeals for the Tenth Circuit for oral argument.

\section{$2.11 .3 \quad$ U.S.Nuclear Regulatory Commission}

During FY 1989, as part of its UMTRCA Title I responsibilities, the NRC completed 57 review activities. These included two RAP reviews, three design reviews, nine inspection plan reviews, two RAP modification reviews, 20 other site-specific reviews, and 18 reviews of yeneric items. In addition, the NRC prepared three Technical Evaluation Reports (IERs) documenting its review of the DOE's remedial action selection for the Riverton, Tuba City, and Spook sites. Inspections of remedial action activities were performed at the Lakeview, Green River, and Spook sites and additional site visits were conducted by NRC technical staff at the Durango, Rifle, Grand Junction, and Green River sites.

During the past year, the NRC examined ways to streamline the UMTRA Project review and concurrence process. Working together to stream?ine a process requiring 12 separate reviews for each site, the NRC and DOE reached several agreements relative to future documentation and reviews: 1) the DOE will prepare one document, supporting NRC concurrence in remedial action selection (design), which focuses on how applicable U.S. Environmental Protection Agency (EPA) standards will be met; 2) the NRC's former concurrence in the Remedial Action Inspection Plan (RAIP) will be incorporated into the remedial action selection concurrence; and 3 ) the NRC 
review of remedial action selection will be condensed into a three-step process, supported by on-site meetings. An additiona! item regarding streamlining the process and basis of NRC concurrence in performance of remedial action is under consideration. In support of the first agreement, NRC prepared and issued a Staff Technical Position on Standard Format and Content for Documentation of Remedial Action Selectioi, at Title I Uranium Mill Tailings Sites.

After the NRC concurs that remedial action is cumplete, the UMTRCA invokes Federal government custody of each site for long-term care. In accordance with the UMTRCA, the NRC will license the DOE (or other agency identified by the President) for this permanent custouy. The NRC, through its Office of Niclear Regulatory Research, is corducting a rulemaking that will modify 10 CFR Part 40 to provide a general license for this purpose.

\subsubsection{U.S. Environmental Protection Agency}

The EPA established the basic standards for cleanup and disposal of tailings from inactive uranium mill sites on March 7, 1983. This fulfilled the EPA's primary responsibility for the remedial action program under Title I of the UMTRCA. On September 3, 1985, however, the U.S. Tenth Circuit Court of Appeals remanded to the EPA the groundwater provisions of these standards, with instructions to replace the qualitative recommendations with quantitative standards similar to those in the standard at 40 CFR 192 for Title II sites. On September 24, 1987, the EPA published proposed replacement provisions in the Federal Register. Final standards have been developed and are currently under review by the office of Management and Budget under E.0. 12291. In developing the final rule, the EPA made use of detailed information provided by the DOE from 14 of the 24 sites covered under Title I.

More generally, the EPA has continued to review and comment on site EISs and EAs, and to consult with Federal, state, and tribal officials, as necessary, to assist with the planning and carrying out of remedial actions. The EPA's headquarters and regional offices plan to continue liaison with the remedial action program, both to provide any needed assistance and to maintain the EPA's surveillance of the practicality and effectiveness of the standards.

\subsection{STATE AND INDIAN TRIBE ACTIVITIES}

Periodic status meetings with state and tribal representatives on Project. activities were continued during Fy 1989 . Excellent cooperation has been extended by all of the participating states and Indian tribes. Their comments are included in Appendix $C$. 


\subsection{STATUS OF DESIGNATED SITES}

\subsubsection{Ambrosia Lake, New Mexico}

The preliminary final RAP was revised to incorporate a new groundwater protection strategy and the final design has been reviewed by the state. The NRC review of the preliminary final RAP was in progres at the end of $F Y$ 1989. The State of New Mexico took sieps to acquire the subsurface rights at the processing site from Hecla Mining Company. The U.S. Army Corps of Engineers reviewed the appraisal of Tract $B$ adjacent to the disposal site. Building demolition was completed in April 1989. Initiation of remedial action on the main site has been delayed until the spring of 1991, unless funding becomes available sroner. The total number of vicinity propert; as requiring remedial action was determined to be three, a? 1 of which are anticipated to be remediated in conjunction with the site remedial action.

\subsubsection{Belfield and Bowman, North Dakota}

The preliminary final RAP and EA were completed and have been reviewed by the state and the NRC. The proposed remedial action is relocation of the Belfield contaminated materials to Bowman with the stabilization of the combined materials at the Bowman site. The RAP site design will be revised after receipt of NRC comments on the documents. The total number of vicinity properties requiring remediation was determined to be eight; they are not anticipated to be remediated until Fi 1992. A statewide referendum will be held in December 1989, affecting tax increases and budget restrictions on state agencies. State funding for the Project may be cut back or eliminated as a result of the vote.

\subsubsection{Canonsburg, Pennsylvania}

Site certification and S\&M activities were continued. Concurrence by the NRC on the DOE's certification of completion of site remedial action is expected in April 1990. All of the vicinity properties were remediated prior to FY 1989. In FY 1989, three completion reports were submitted and 18 vicinity properties were certified, which brings the total number of vicinity property certifications to 151 out of a total of 162 requiring remedial action.

\subsubsection{Durango, Colorado}

Relocation of the tailings was completed in FY 1989 with approximately 1.4 million cubic yards of tailings placed in the Bodo Canyon disposal cel1. During FY 1990 
the cover will be placed on the disposal cell. In FY 1989, 14 vicinity property Radiological and Engireering Assessments (REAs) were submitted, bringing the total to date to 126. Construction on 19 properties was initiated, for a total of 126 vicinity properties that have had remedial action initiated out of the 126 estimated to be eligible for remedial action. In FY 1989, 24 completion reports were submitted and 54 vicinity properties were certified, which brings the total number of vicinity property certifications to 65 .

\subsubsection{Edgemont, South Dakota}

In FY 1989, construction on one property was initiated and completed, for a total of 136 vicinity properties that have had remedial action completed out of the 137 properties estimated to be eligible for remedial action. In FY 1989, 23 completion reports were submitted and 22 vicinity properties were certified, which brings the total number of vicinity property certifications to 99.

\subsubsection{Falls City, Texas}

The draft EA and RAP were completed in FY 1988, but review time was held up due to the priority of other sites. This year's efforts have focused on sathering additional groundwater data in an offort to develop a compliance strategy to meet the proposed EPA groundwater standards. The preferred alternative remains stabilization on site (SOS). At the request of local Falls City residents, a vicinity property cleanup program was started earlier than originally planned. In total, seven vicinity properties were cleaned up with the contaminated materials moved to the former Susquahanna-Western mill site. Vicinity property cleanup was finished by November 30 , 1989.

\subsubsection{Grand Junction, Colorado}

The Record of Decision (ROD) issued in August 1988, called for the relocation of the tailings to the Cheney disposal site. Bids were received in October 1988. The bid document provides for two bid alternatives for transporting the contaminated materials: 1) to the Cheney site by train/truck; and 2) to the Cheney site by truck only. The Phase II construction contract was awarded in December 1988 to Industrial Constructor Corporation (ICC) for truck-only haul of the tailing to the Cheney site. Subsequent issues, involving the county Conditional Use Permit (CUP) restrictions for the truck-only mode in conjunction with the need for additional site characterization at Cheney to demonstrate compliance with 
the EPA groundwater standards necessitated unforeseen delays in initiation of the Phase II remedial action. As a result of the CUP restrictions, the train/truck mode was determined to be the only option that would complete the project by the Congressionally mandated date of 1994. A detailed site characterization program was conducted during the summer and fall of 1989 to determine the suitability of the cheney site. The formal decision to implement the train/truck mode to Chenev was announced in December 1989.

During FY 1989, 697 vicinity property REAs were submitted, bringing the total to date to 3,396 . Construction on 658 properties was initiated, bringing the total to 2,760 vicinity properties that have had remedial action initiated out of the 4,114 properties estimated to be eligible for remedial action. Also in Fy 1989, 782 Completion Reports were submitted and 795 vicinity properties were certified, which brings the total number of vicinity property certifications to 1,685 .

\subsubsection{Green River, Utah}

Ground was broken at the site in November 1988. The final RAP describing the proposed remedial action was prepared and sent to the NRC. Several revisions to the site design were made due to NRC comments, and the determination that there were more contaminated materials than originally were anticipated. Remedial action was 62 percent completed by the end of FY 1989, and was scheduled for completion in December 1989. This is the first site to be constructed for which there is a groundwater compliance strategy in the RAP designed to meet the EPA's groundwater protection standards. Construction on six vicinity properties was initiated, bringing the total to 17 vicinity properties that have had remedial action initiated out of the 19 properties estimated to be eligible for remedial action. In FY 1989, 11 completion reports were submitted and five vicinity properties were certified, which brings the total number of vicinity property certifications to five.

\subsubsection{Gunnison, Colorado}

Another phase of hydrogeological characterization began in August 1989 at the Landfill disposal site. Earlier characterization at the site revealed a more complicated groundwater regime than was originally anticipated and more data war needed to demonstrate compliance with the EPA grointwiter standards. The draft RAP and draft EA will be issued for review in mid-1990. A major part of the site design was completed in FY 1989. One major hurdle that has delayed site progress was the refusal of the tailings site owners to allow additional characterization of the tailings pile 
and mill site. The characterization is needed prior to completing the groundwater protection strategy. The total number of vicinity properties requiring remedial action was determined to be nine; these are not anticipated to be remediated until FY 1991.

\subsubsection{Lakeview, Oregon}

The DOE completed remedial action at the site in early October 1989, and held a formal closing ceremony on October 12. Remedial action was campleted by the recompaction of the radon barrier, the placement of a rock erosion protection system, and the placement of a soil matrix in the topsoil rock. Design modifications requested by the state and the NRC accounted for the delay in completion until 0ctober. The total number of vicinity properties requiring remediation was determired to be eight, all of which were remediated prior to FY 1989. In FY 1989, two Completion Reports were submitted and three vicinity properties were certified, which brings the total number of vicinity property certifications to three.

\subsubsection{Lowman, Idaho}

Work on the draft EA and draft RAP was reprioritized and, subsequently, scheduled delivery dates for these documents slipped in favor of higher-priority sites. The draft RAP is scheduied to be issued for review in February 1990 and the FONSI in January 1990. During the state's FY 1989, the UMTRA Project was successful in receiving initial funding commitments from the State of Idaho. Engineering work for the 28 vicinity properties was initiated in $F Y$ 1989. REA submittals and remedial action are scheduled to begin in FY 1990, pending state funding support.

\subsubsection{Maybe11, Colorado}

During FY 1989, site characterization was expanded to allow for additional data gathering to support the current design and provide sufficient data to develop a groundwater compliance strategy to meet the proposed EPA groundwater standards. Site characterization and revisions to the draft RAP and EA are expected in FY 1990. The total number of vicinity properties requiring remedial action was determined to be three, all of which are scheduled to be remediated in FY 1991.

\subsubsection{Mexican Hat, Utah}

The final RAP is scheduled for publication in March 1990. Phase I remedial action, consisting primarily of 
demolition of mill buildings, was completed in october 1987. Phase II, which consists of all remaining remedial action work, was initiated in September 1988 and during FY 1989 was 31 percent completed, along with the Monument Valley tailings. (see Monument Valley, below, for further details). All remedial action work at both sites is scheduled to be suspended, as of February 1990 until October 1990, as a result of budgetary restrictions. In FY 1989, construction was initiated on one out of the nine vicinity properties estimated to be eligible for remedial action.

\subsubsection{Monument Valley, Arizona}

In March 1988, a decision was reached to reissue a preliminary final $E A$ in order to incorporate a design for codisposal at Mexican Hat rather than SOS. The final EA was completed and the FONSI issued in March 1989. Rather than reissue a final RAP for Monument Valley, the Mexican Hat RAP was revised to reflect the codisposal option through RAP modifications. Site remedial action work was initiated in May 1989 and was 31 percent complete as of the end of the year. No additional vicinity properties were located as a result of radic, ogical survey work during FY 1989. The one property to be included will undergo a REA during FY 1990.

\subsection{3 .15 Naturita, Colorado}

The Dry Flats disposal site was selected as the preferred option during FY 1989. The draft RAP and draft EA are scheduled for completion in April 1990. The total number of vicinity properties requiring remedial action was determined to be 19, al1 of which are anticipated to be remediated in FY 1991 .

\subsubsection{1d and New Rifle, Colorado}

The Phase I demolition at both the 01d and New Rifle sites was completed in September 1989. Phase II construction, the actual relocation of the mill tailings to Estes Gulch, is pending approval of the EIS and RAP, and project funding. Approval of the final EIS is expected in Tate Decemier 1989 and a ROD is expected in late February 1990. Approval of the RAP should also occur in late February 1990. Site Remedial action is scheduled to start October 1990.

Vicinity property cleanup began in April 1989 and is currently ongoing. Two packages totalling 19 properties were completed in FY 1989, with the third package of nine properties expected to be finished by the end of December 
1989. Also in FY 1989, 25 vicinity property REAs were submitted, bringing the total to date to 32 . As of the end of FY 1989, 29 properties, including one property initiated by the state, had been initiated out of a total of 96 estimated to be eligible for remediation.

\subsubsection{Riverton, Wyoming}

Relocation of the tailings to the UMETCO disposal site continued in FY 1989 and remedial action was 71 percent finished as of September 30, 1989, which is well ahead of the original schedule. All vicinity property remedial action was completed in FY 1989. There were 14 vicinity property REAs submitted in FY 1989, bringing the total to date to 37. During FY 1989 construction on 22 properties was completed, bringing the total to 37 vicinity properties that have been remediated out of the total of 37 properties estimated to be eligible for remedial action. In FY 1989, four completion reports were submitted and two vicinity properties were certified, which brings the total number of vicinity property certifications to seven.

\subsubsection{Salt Lake City, Utah}

During FY 1989 placement of the cover and site restoration at the clive disposal site was finished. The site completion report is expected to be completed by the state in February 1990, and certification is expected later in FY 1990. The total number of vicinity properties requiring remedial action was determined to be 119, all of which were remediated prior to FY 1989. In FY 1989, 12 completion reports were submitted and 41 visinity properties were certified, which brings the total number of vicinity property certifications to 96 .

\subsubsection{Shiprock, New Mexico}

Site and vicinity poperty certification is underway and is expected to be compieted in FY 1990. Additional data from groundwater characterization conducted along the San Juan River was compiled in a modification to the RAP and associated floodplain characterization report. The total number of vicinity properties requiring remedial action was determined to be 15, al? of which were remediated prior to FY 1989. In FY 1989, one vicinity property was certified. This brings the total nuiber of vicinity property certifications to 11 . It is anticipated that all properties will be certified in FY 1990. 


\subsubsection{Slick Rock, Colorado}

Additional characterization of the Union Carbide processing site was performed during FY 1989 and completed in late october. The conclusion is that SOS will not be able to meet the proposed EPA groundwater standards. Alternative sites are now being identified. Failing the identification of an acceptable alternative site, one other option is to collocate the tailings with the Naturita material at the Dry Flats disposal site. The total number of vicinity properties requiring remedial action was determined to be four, all of which are anticipated to be remediated in FY 1992.

\subsubsection{Spook, Wyoming}

Discussions continued with officials from the state's Abandoned Mined Lands (AML) program in support of a joint AML/UMTRA Project remedial action for the site. The decision was made to combine the two programs under one contract, with separate program-specific line items. The preliminary design was completed in April 1988, and additional groundwater characterization was completed in August 1988 to facilitate compliance with the proposed EPA groundwater standards. Additional drilling and sampling in the acid pond area was also required to complete thorium characterization at depth. The decision to apply for supplemental standards for groundwater compliance was made in September 1988. The final EA was completed and the FONSI published in March 1989. Construction on both the AML and UMTRA portions of the work started in April 1989 and was completed, with the exception of the surveillance and maintenance work, in September 1989 for the UMTRA portion and in November 1989 for the AML portion. The total number of vicinity properties requiring remedial action was determined to be one, which was remediated in FY 1989. The completion report submittal is scheduled for FY 1990.

\subsubsection{Tuba City, Arizona}

Phase II remedial action started in January 1988. The test fill for the low permeability features of the cover was constructed in April and laboratory testing of the placed cover samples was completed in August 1988. The design permeability was achieved, and NRC concurrence to place the cover was received in october 1988. The NRC issued their final TER and conditionally concurred in the final RAP in July 1989. Groundwater cleanup still remains an open issue and has been deferred until promulgation of the EPA's final groundwater protection standards. The 
final RAP was published August 1989. Final site remedial action is scheduled for completion in March 1990. The total number of vicinity properties requiring remedial action was determined to be one, which was remediated prior to FY 1989. In FY 1989, one completion report was submitted. It is anticipated that this property will be certified in FY 1990. 
APPENDIX A

PROGRAM FUNDING

$-1$ 


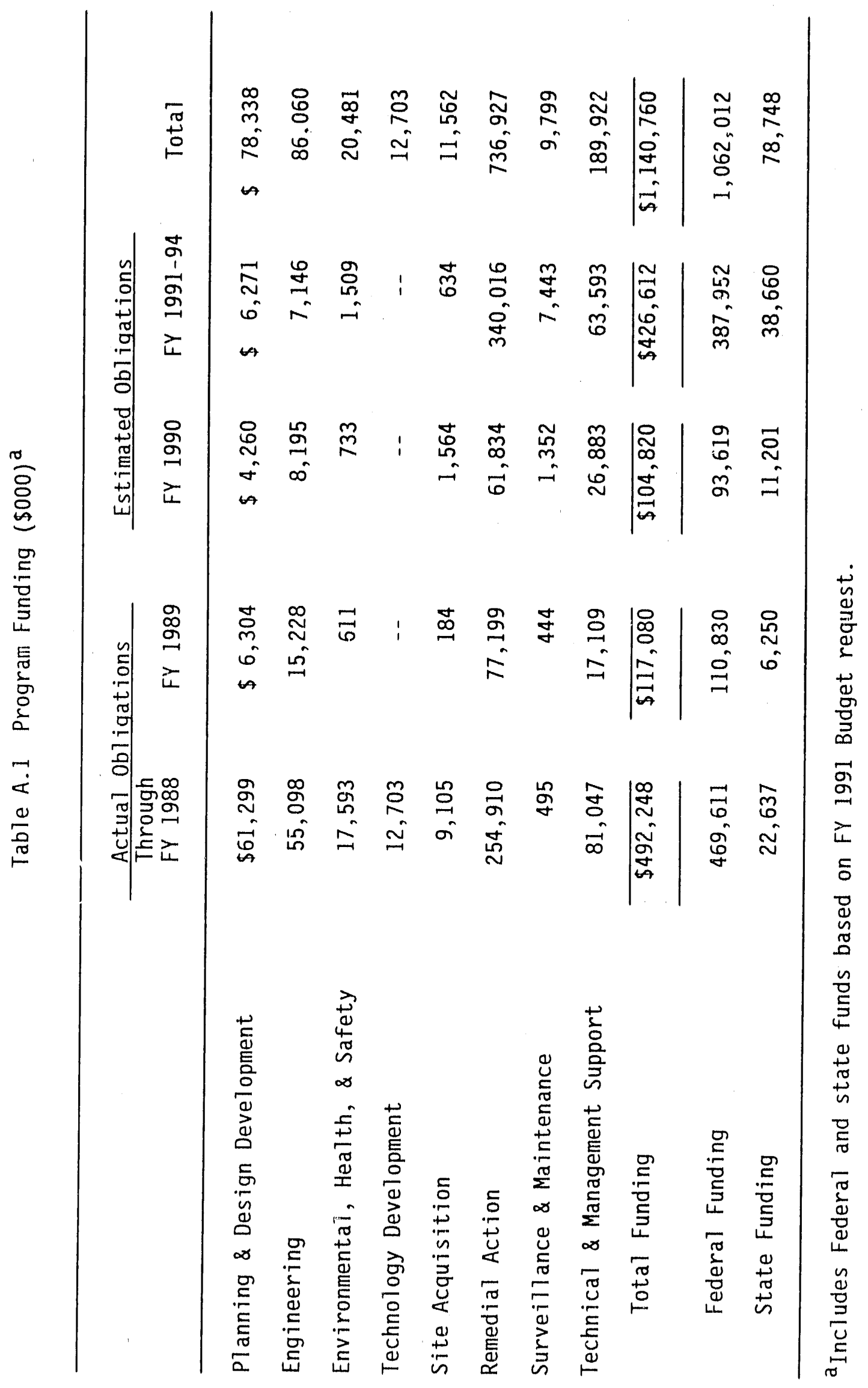


APPENDIX B

FIGURES AND TABLES 


\section{APPENDIX B \\ FIGURES AND TABLES \\ TABLE OF CONTENTS}

Figure

Page

Figure B.1 UMTRA Site Locations . . . . . . . . . . . . . . B-1

Figure B.2 UMTRA Project Schedule. . . . . . . . . . . . . . B-2

Table

Table B.1 Processing Sites Summary. . . . . . . . . . . . B-3

Table B.2 Summary Processing Sites Activities Completed as

of end of FY 1989................. B-4

Table B.3 Vicinity Properties Activities Summary. . . . . . . . . B-5 


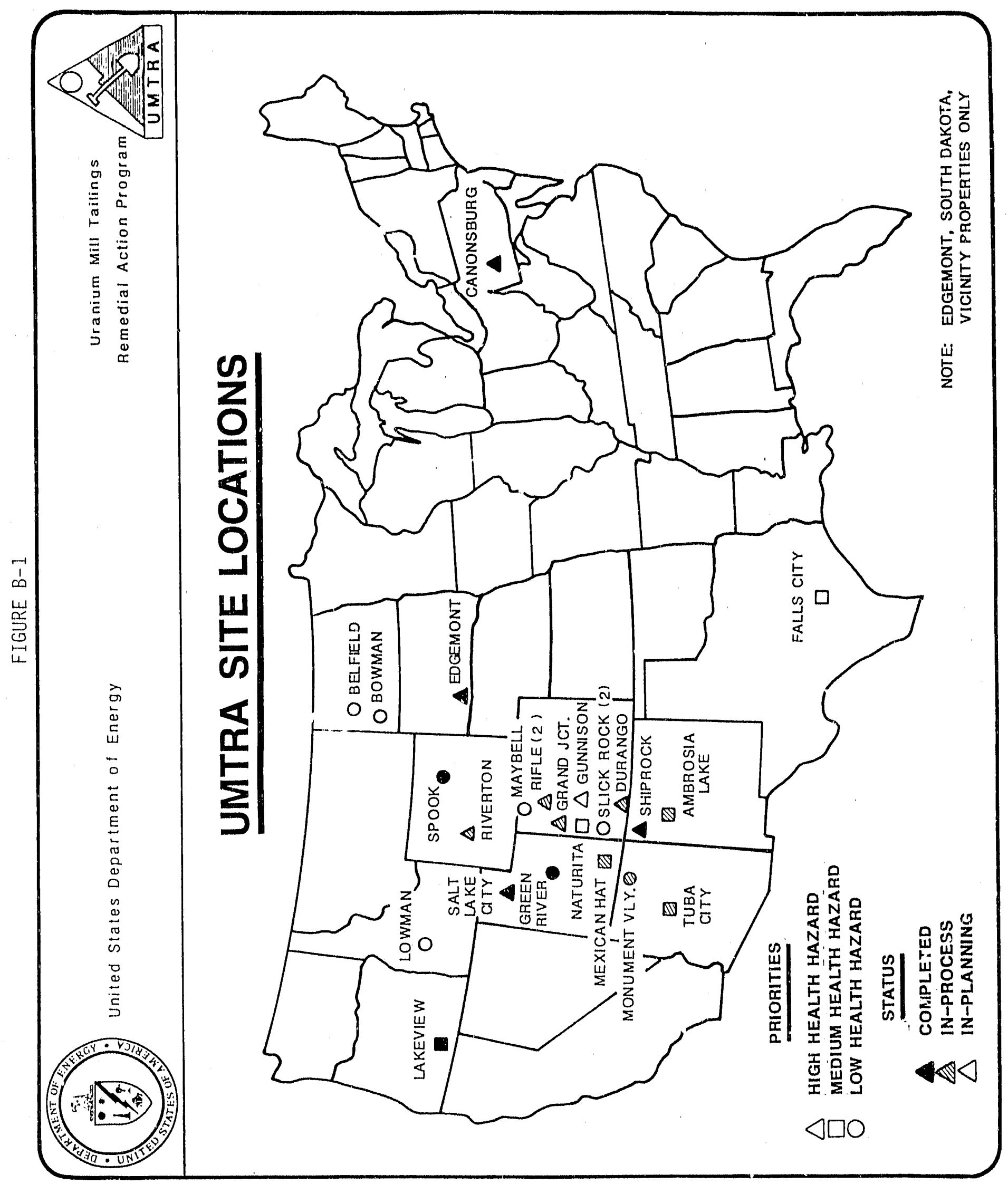




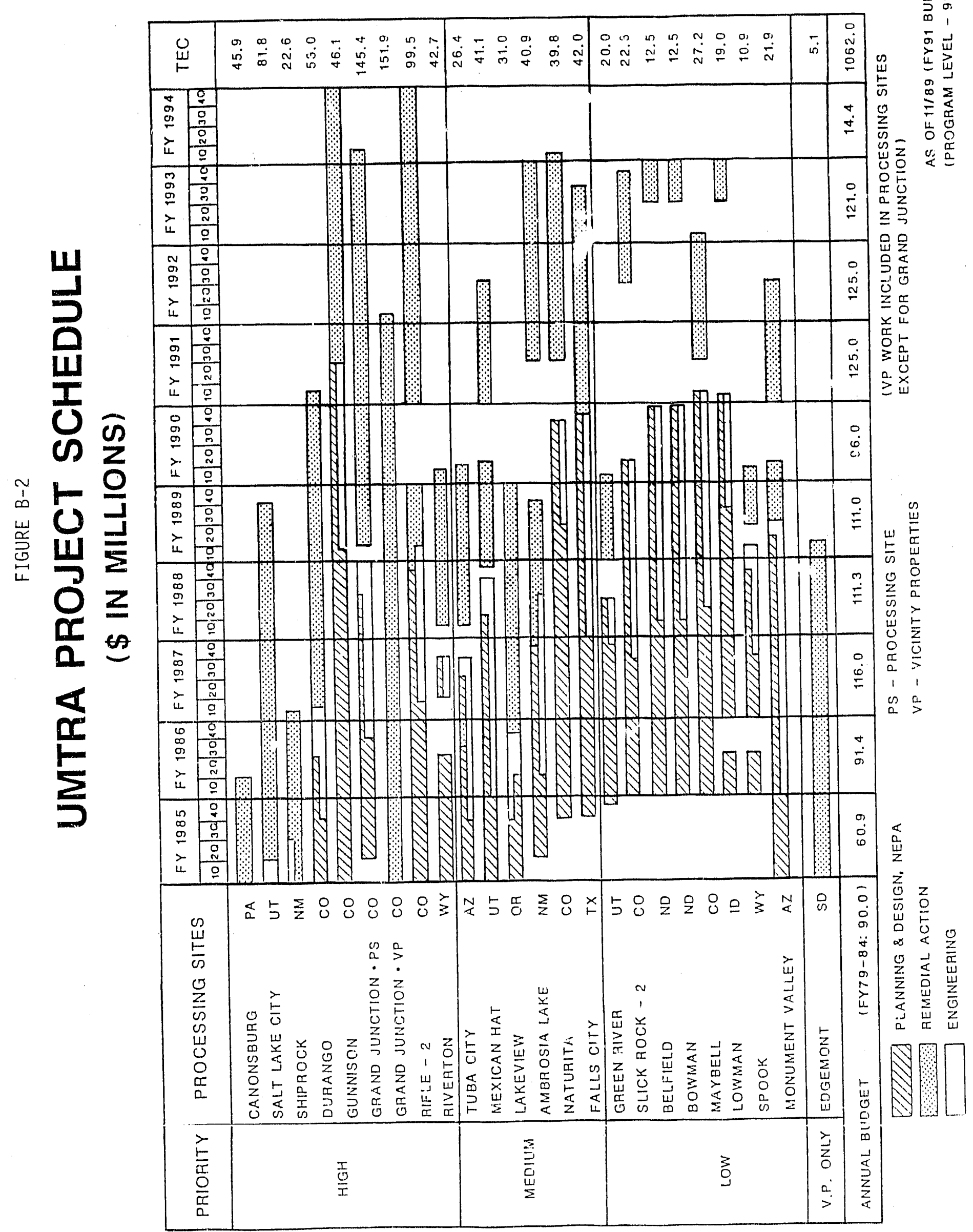


Table B.1 Processing Sites Summary

\begin{tabular}{|c|c|c|c|}
\hline State & Processing Site & $\begin{array}{l}\text { Taijingsa } \\
\left.\text { (10 }{ }^{3} \text { cys }\right)\end{array}$ & $\begin{array}{l}\text { NEPA document/ } \\
\text { proposed action } \mathrm{c}\end{array}$ \\
\hline Arizona & $\begin{array}{l}\text { Monument Yalleyb } \\
\text { Tuba Cityb }\end{array}$ & $\begin{array}{r}1,083 \\
779\end{array}$ & $\begin{array}{l}\text { EA/Relocate } \\
\text { EA }\end{array}$ \\
\hline Colorado & $\begin{array}{l}\text { Durango } \\
\text { Grand Junction } \\
\text { Gunnison } \\
\text { Maybell } \\
\text { Naturita } \\
\text { Rifle (O1d \& New) } \\
\text { Slick Rock (NC \& UC) }\end{array}$ & $\begin{array}{r}1,400 \\
2,841 \\
492 \\
2,889 \\
615 \\
2,745 \\
328\end{array}$ & $\begin{array}{l}\text { EIS/Relocate } \\
\text { EIS/Relocate } \\
\text { EA/Relocate } \\
\text { EA EA/Relocate } \\
\text { EIS/Relocate } \\
\text { EA/Relocate NC to UC }\end{array}$ \\
\hline Idaho & Lowman & 60 & EA \\
\hline New Mexico & $\begin{array}{l}\text { Ambrusia Lake } \\
\text { Shiprock }\end{array}$ & $\begin{array}{l}2,659 \\
1,079\end{array}$ & $\begin{array}{l}E A \\
E A\end{array}$ \\
\hline North Dakota & Belfield/Bowman & 151 & $\begin{array}{l}\text { EA/Relocate Belfield } \\
\text { to Bowman }\end{array}$ \\
\hline Oregon & Lak itew & .52 & EA/Relocate \\
\hline Pennsylvania & Canonsburg & 173 & EIS \\
\hline Texas & Falls City & 4,614 & EA \\
\hline Utah & $\begin{array}{l}\text { Green River } \\
\text { Mexican Hatb } \\
\text { Salt Lake City }\end{array}$ & $\begin{array}{r}210 \\
2,723 \\
2,710\end{array}$ & $\begin{array}{l}\text { EA } \\
\text { EA } \\
\text { EIS/Relocate }\end{array}$ \\
\hline Wyoming & $\begin{array}{l}\text { Spook } \\
\text { Riverton }\end{array}$ & $\begin{array}{r}160 \\
1,503\end{array}$ & $\begin{array}{l}\text { EA } \\
\text { EA/Relocate }\end{array}$ \\
\hline
\end{tabular}

aDoes not inc'ude windblown coniamination, rubble, or vicinity properties material. Figures for Belfield, Bowman, and Naturita reflect residual contamination only, since there are no tailings at those sites.

b processing site on Indian tribal lands.

${ }^{C}$ Assumes all sites not otherwise designated will re stabilized in place (SIP) or on site (SOS) pending completion of environmental and engineering studies. 


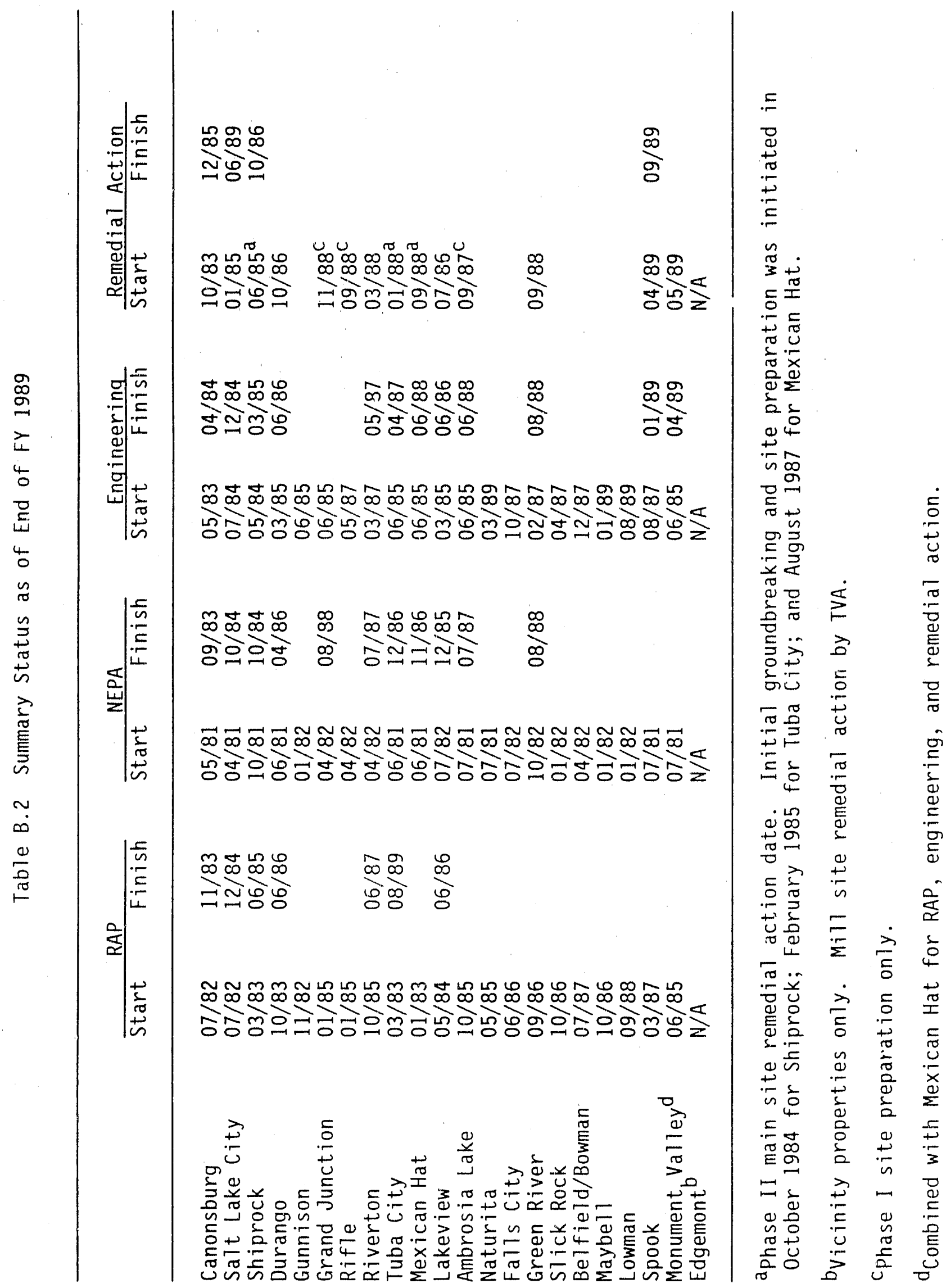




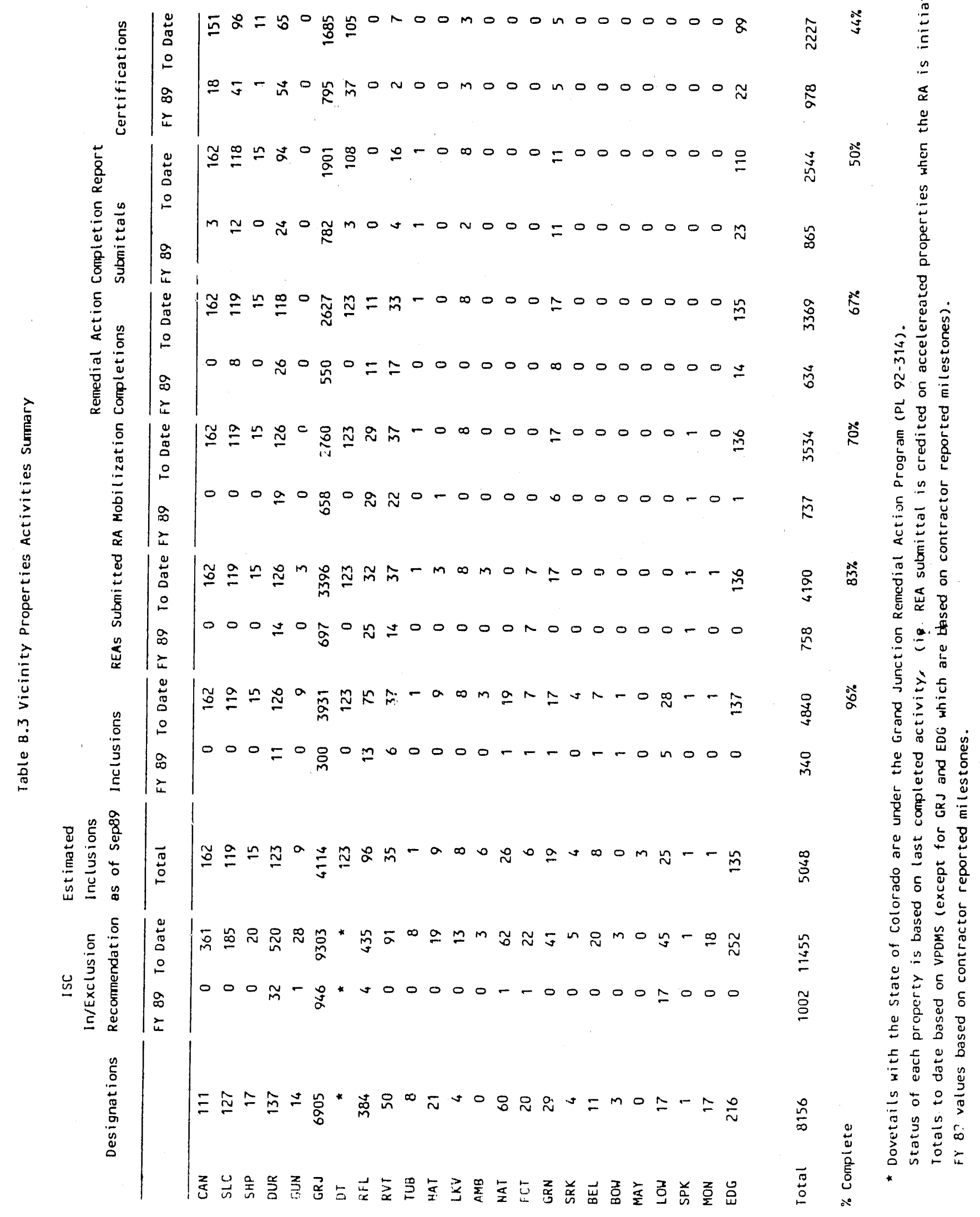


APPENDIX C

COMMENTS FROM STATES AND TRIBES 


\author{
APPENDIX C \\ COMMENTS FROM \\ STAII. AND TRIBLS
}

Section

Page

State of New Mexico. . . . . . . . . . . . . . . . . C-1

State of North Dakota. . ................. . C-3

Commonwealth of Pennsylvania................ . C-7

State of Texas...................... . . . . 9

State of Wyoming..................... . C 11

Navajo Nation. . . . . . . . . . . . . . . . . C -13 


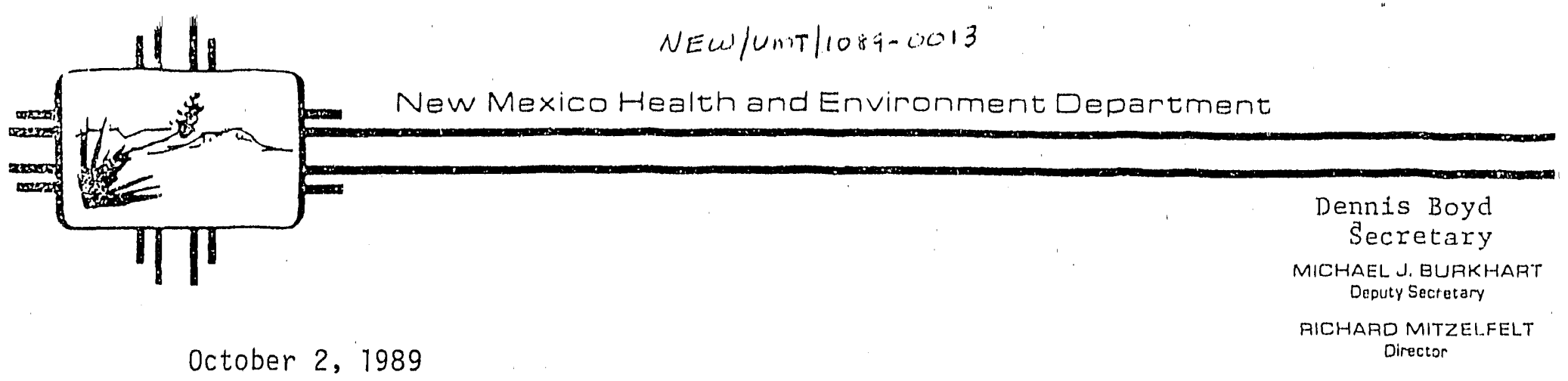

Mr. Mark L. Matthews

Acting Project Manager, UMTRA

Department of Energy and Minerals

P. 0. Box 5400

Albuquerque, New Mexico 87115

Dear Mr. Matthews:

This letter is in regards to the 1989 UMTRA Project Annual Status Report.

The Low Level Radioactive Waste Section (LLRWS) of the Special Waste Bureau participated in the ongoing subsurface acquisition of Tract $A$ of the Ambrosia Lake Phillips site reclamation program and is progressing in the property acquisition of Tract $B$.

The LLRWS contact person and staff conducted reviews of documents and technical reports, attended meetings pertirient to the Uranium Mill Tailings remedial Action Project (UMTRA) and conducted visits to the Phillips Mill and Tailings site.

Documents reviewed and commented on are:

- Moisture Contents and Unsaturated Conditions in UMTRAP Radon Barriers, January 1989

- Regulatory Alternatives For Groundwater Compliance for the DOE's UMTRA Project, March 1989

- UMTRAP Environmental Health and Safety Plan, February 1989

- RAP and Disposal Cel1 Design, January 1989

- Technical Approach Document, May 1989

- Performance Assessment of Select Covers and Disposal Cell Compliance with EPA Groundwater Standards, June 1989

- RAP and Site Design for the Stabilization of the Inactive Uranium Mill Tailings at Ambrosia Lake, New Mexico, July 1989

- Stiff Technical Positions: Design of Erosion Protection Covers for Stabilization of Uranium Mill Tailings Sites, August 1989 
Mark L. Matthews

October 2, 1989

Page 2

If more detailed information is required, please contact Eloy $\mathrm{J}$. Montoya at (505) 827-2952 or Willy Abeele at (505) 827-2955.

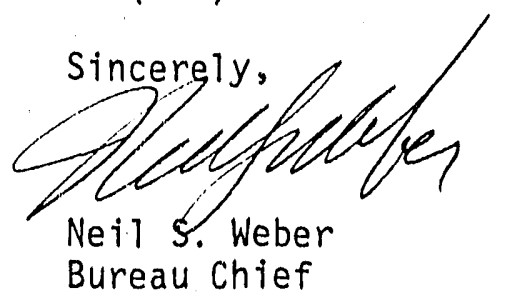

NSW: EJli/ms 1

xc: File 


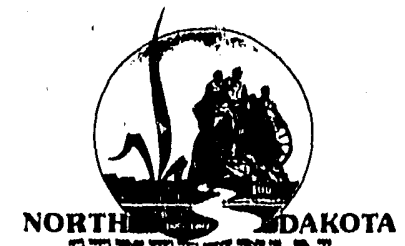

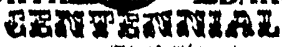

NOK IUMT/1069-0007

NORTH DAKOTA

STATE DEPARTMENT OF HEALTH

AND CONSOLIDATED LABORATORIES

State Capltol

Blsmarck, North Dakota 68605

ENVIRONMENTAL HEALTH SECTION

October 9, 1989

$1200 \mathrm{Mlssourl}$ Avenue

P.O. Box 5520

Blsmarck, North Dakota 58502.5520

Mr. Mark L. Matthews

Acting Project Manager

Uranium Mill Tailings

Project office

U.S. Department of Energy

Albuquerque Operations of Eice

P.D. BOX 5400

Albuquerque, NM 87115

Dear Mr. Matthews:

Referenced is your memorandum of september 13, 1989, requesting input for the FY-1989 UMTRA Project Annual status Report. A brief summary of UMTRA-related activities for the Belfield and Bowman sites during Federal Fiscal Year 1989 is provided below for your consideration in preparing your Annual status Report:

\section{Eirst Quarter FY 1989}

- The Department received and endorsed Modification No. A003, to Cooperative Agreement No. DE-FCO4-82AL20536.

- Meetings were conducted with state officials and the U.S. Department of Energy (DOE) in Bismarck on November 2, 1989, and locally in Bowman, North Dakota with the Bowman County Comission and local landowners on November $3,1989$.

- MK-Ferguson Company forwarded a cultural resources inventory request to the state Historical Society for approval (which was granted on November 21,1988 ).

- The DOE UMTRA Project trip report for the November 3, 1988, meeting with local landowners contains several landowner concerns regarding the UMTRA projects in North Dakota (recorded in meeting minutes).

- The North Dakota state Highway Department forwarded a road project proposal to this Department for review and comment (Anidon-Bowman, North Dakota). This road project may impact upon the 1992 scheduled UIMTRA construction activities in North Dakota. 
Second Quarter FY 1989

- Briefing kits were provided by DOE regarding UMTRA projects (Belfield/Bowman) for SB2094 Testimony to the North Dakota Legislature.

- Comments were prepared by the Department regarding the 1992 state Highway project betweon Amidon-Bowman, North Dakota.

- Department personnel testified before the North Dakota Legislative Senate Appropriations Committee for SB2094 (UMTRA funding) on January 27, 1989 and Eebruary 6, 1989. SB 2094 passed the senate $(\mathrm{Y}: 49 \mathrm{~N}: 0)$ on February 9, 1989. Testimony was also provided to the House Appropriations Comrnttee on March 10, 1989.

- Vicinity Property No. BO-00l (Soderstrom) was included by DOE in UMTRA Projects Remedial Action Plan (RAP).

- The Department forwarded a local citizen's concerns regarding the North Dakota UMTRA projects to DOE for resolution (regarding alternate siting of the disposal cell for UMTRA site contaminated matorials on federal lands).

Third Quarter FY 1989

A briefing was conducted with Bowman County Commissioners/State/DOE and Jacobs Engineering on April 4, 1989.

- A meeting (regarding title search and site acquisition) was conducted with state and DOE officials on April 5, 1989.

- The DOE forwarded final design documents for the Belfield/Bowman UMTRA projects to North Dakota on April 10 , 1989.

- SB2094 passed the North Dakota House (Y:102 13:1) on Apri1 13, 1989.

- The North Dakota Geological Survey provided background data on Molybdenum occurring in North Dakota lignite to the Department for answering a citizen inquiry. (Jacobs Engineering also provided background information to the Department on Molybdenosis in livestock).

- SB2094 was signed by the Governor on May 1, 1989. to authorize $\$ 140,000$ biennial funding for 108 UMTRA state matching funds. 
: The Department requested assistance in site acquisition activities from the state Highay Department on May $25,1989$.

- The Department executed copies of Modification No. Mo04 to Cooperative Agreement witin the DOE on June 7, 1989.

- The doe sent a lettar on June 8, 1989, to a local citizen (Soderstrom) regarding questions ralsed at public meetings in ivorth Dakota.

- This Department sent a site acquisition proposal schedule to the DOE on June 17, 1989 regarding the state Highway Department assistance timetable.

Eourth Quarter FY 1989

- This Department reviewed the DoE distributed preliminary Final RAP, dated July 1989.

- The DOE forwards final bienndal billing on August 8, 1989, to North Dakota for the UMTRA projects in the amount of $\$ 5,156.00$ through June 30,1989 (Balance $=\$ 23,018.00$ credit).

- The DOE approves state Highway Department schedule for site acquisition assistance on August $15,1989$.

- This Department requests federal funding data for UMTRA projects from Jacobs Engineering on September 21, 1989, per governor's request for referral information. (Jacobs Engineering provided federal funding data to Department, as requested on September 21-22, 1989).

If you have any questions regarding theso itens, please feel free to contact this Department at (701)224-2348.

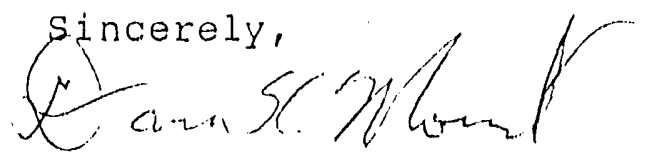

Dana K. Mount, P.E.

Director, Division of

Environmental Engineering

DKM/TDL : jsd

Encl: 


\section{COMMONWEALTH OF PENNSYLVANIA DEPARTMENT OF ENVIRONMENTAL. RESOURCES}

BUREAU OF RADIATION PROTECTION Highland Bullding

121 South Highland Avenue

Pittsburgh, Pennsylvania 15206-3988

(412) 645-7100 (answers 24 hrs.)

October 12, 1989

Mark L. Matthews

Acting Project Manager

Uranium Mill Tailings Project Office

5301 Central Avenue, NE; Suite 1700

Albuqueque, NM 87108

Dear Mark:

As requested by your memorandum of September 13, 1989 (concerning information for the 1989 UMTRA Project Annual Status Report), please be advised that since no significant UMTRA - related activities have occurred during the past federal fiscal year, the Commonwealth of Pennsylvania has no specific items for inclusion in this report.

We are pleased, however, that some action by the federal government has begun regarding the annotation of vicinity property land records.

of course, Mark, if you have questions concerning this, please do not hesitate in contacting us.

Sincerely,

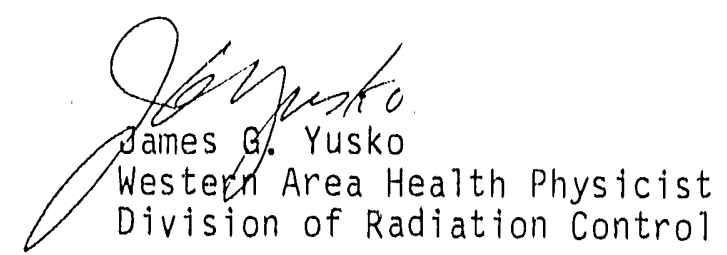

$J G Y: n j h$

CC: L. C. Brazley 


\section{TEX / U mT/1089-0015

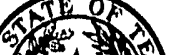 \\ (S) \\ (2) \\ Texas Department of Health}

Robert Berristein, M.D., F.A.C.P.

Commissioner
1100 West 49 th Street

Austin, Texas 78756.3189

(512) 458.7111

Radiation Control

(512) 835-7000
Robert A. MacLean, M.D.

Deputy Commissioner Professional Services

Hermas L. Miller

Deputy Commissioner

Management and Administration

October 4, 1989

Mr. Mark L. Matthews

Acting Project Manager

Urantum Mili Tailings Project office

U. S. Department of chergy (DOE)

Albuquerque Operations office

P.O. BOX 5400

Albuquerque, NM 87115

Dear Mr. Matthews:

Enclosed is a summary of Uranium Mill Tailings Remedial Action (UMTRA)

Project activities at the Falls City site for inclusion in the 1989 UMTRA

Project Annual Status Report.

If you have any questions concerning the report, please call me.

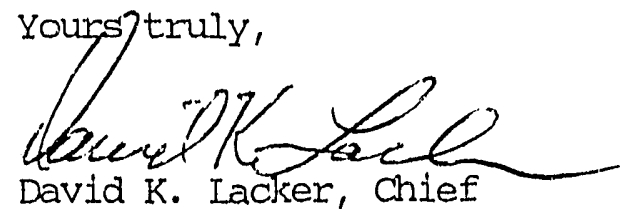

David K. Lacker, Chief

Bureau of Radiation Control

Enclosure

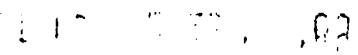




\section{UMIRA Project. Status Report FY 1989 \\ Falls City Site}

The Final Design for Review for the Falls Clty site was published. The State's suggestions for a vegetative cover and topsolil replacement were made a part of the plan; however, the extent of intended replacement of topsoil still remains a concern. A decision on groundwater restoration is sti.11 waiting on the establishment of standards by the Environmental Protection Agency (EPA).

Title searches and surveys were completed on the properties involved in the restoration pian. Surface appraisals have begun and minera.l rights appraisals are currently in the bidding stage. The process to transfer deed of the Solution Engineering property to the state of Texas Department of Health has begun with the help of the state of Texas General Iand office.

Remedial action contracts between the Department of Energy (DOE), State and home owners were finalized on six of seven vicinity properties. Work will begin once a contractor is found to do the cleanup.

During the year, there were two meetings of the Falls City Task Force and representatives from MK-Ferguson, DOE and the Texas Department of Health (IDH). TDH representatives attended a $60 \%$ design engineering meeting at the San Francisco headquarters of MK-Ferguson in October of 1988. Meetings were held in November of 1988 and May of 1989 with all interested state agencies to discuss the Remedial Action Plan. 
MIKE SULLIVAN GOVERNOA

\section{Department of Environmental Quality}

210 Lincoln Street

Air Quality Division (307) 332.3144
Land Quality Division (307) 332.3047
- Lander, Wyoming 82520

Solid Waste Management Program (307) 332.3144

Water Quality Division (307) 332.3144

\section{November 2, 1989}

Mr. Mark Matthews

U. S. Dept, of Energy

Albuquerque Operations office

First National Bank Bldg.

5301 Ceritral Ave., N.E.

Suite 1700

Albuquerque, NM 87108

RE: 1989 LMTRA Project Annual Status Report

Dear Mr. Matthews:

As requested by your september 13, 1989 letter, the state of wyoming is pleased to providc the following sumary of activities during fiscal year 1989 (October 1, 1988 - September 30, 1989):

1. The Riverton processing site was approximately $90 \%$ completed.

2. Remcdial action on 37 of 41 Vicinity Properties near the Riverton site was completed.

3. Remedial action at the Spook processing site is a cooperative effort between UMTKA and the hyoming Abandoned Mine Lands Program (AML.). As of september 15, 1989, the UMTRA portion of the project was completed.

4. The Sfock site Vicinity property was completed.

Should you have any questions regarding this report, please feel tree to contact me.

$\mathrm{JE}: \mathrm{mI}:$
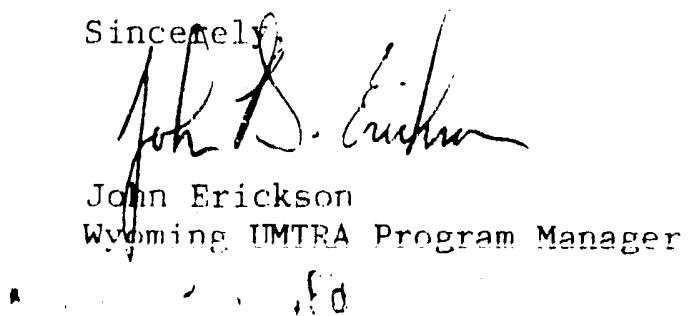

Xi: Roger Shaffer - Cheyenne DEQ-LQD

Jim Uzzell - Cheyenne DEQ-LQD 


\section{THE NAVAJO NATION}

Leonard Haskie Interim Chairman Navajo Tribal Council
Irving Billy Interim Vice Chairman Navajo Tribal Council

October 03, 1989

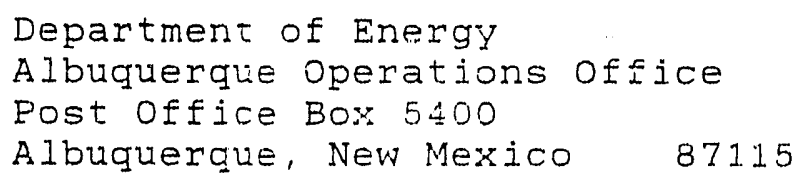

Re: 1989 UMTRA Project Annual status Repont

Dear Mr. Matthews:

This letter is to inform your office that the Navajo UMTRA Program will not be submitting any formal input for the UMIRA Annual status Report. However, we would like a copy of the Annual Report sent to our office whenever it becomes available for distribution.

If any questions should arise, please call me at 871-6359.

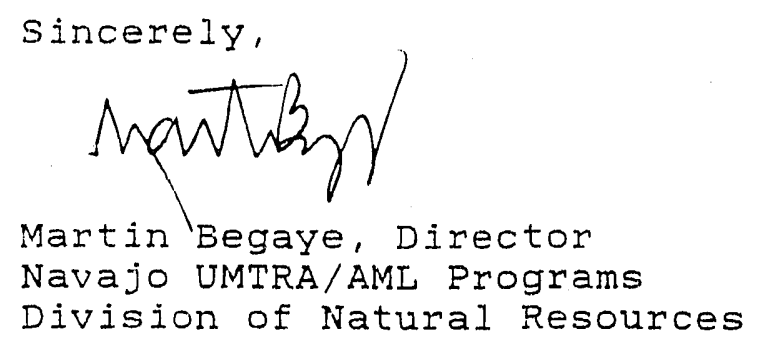


APPENDIX D

PHOTOGRAPHS OF REMEDIAL ACTIONS 


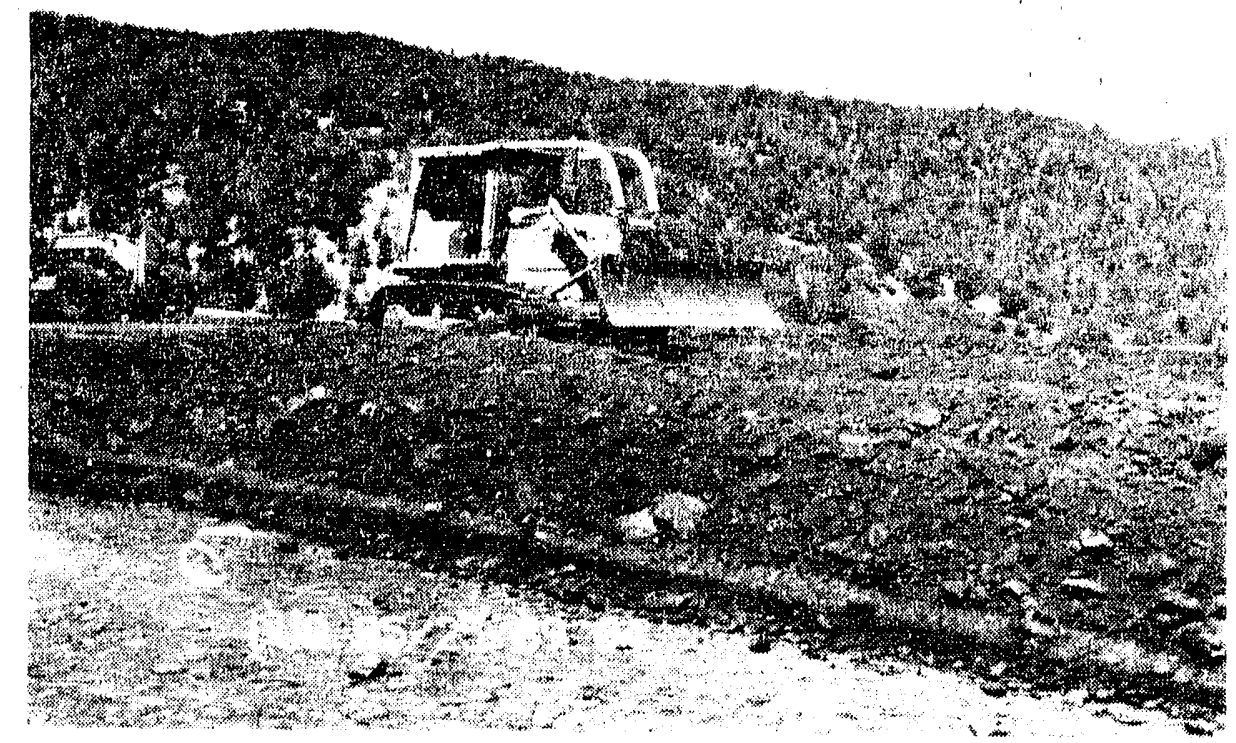

Preparing the disposal cell embankment at Bodo Canyon, CO disposal site for placement of contaminated material from Durango, CO, processing site.

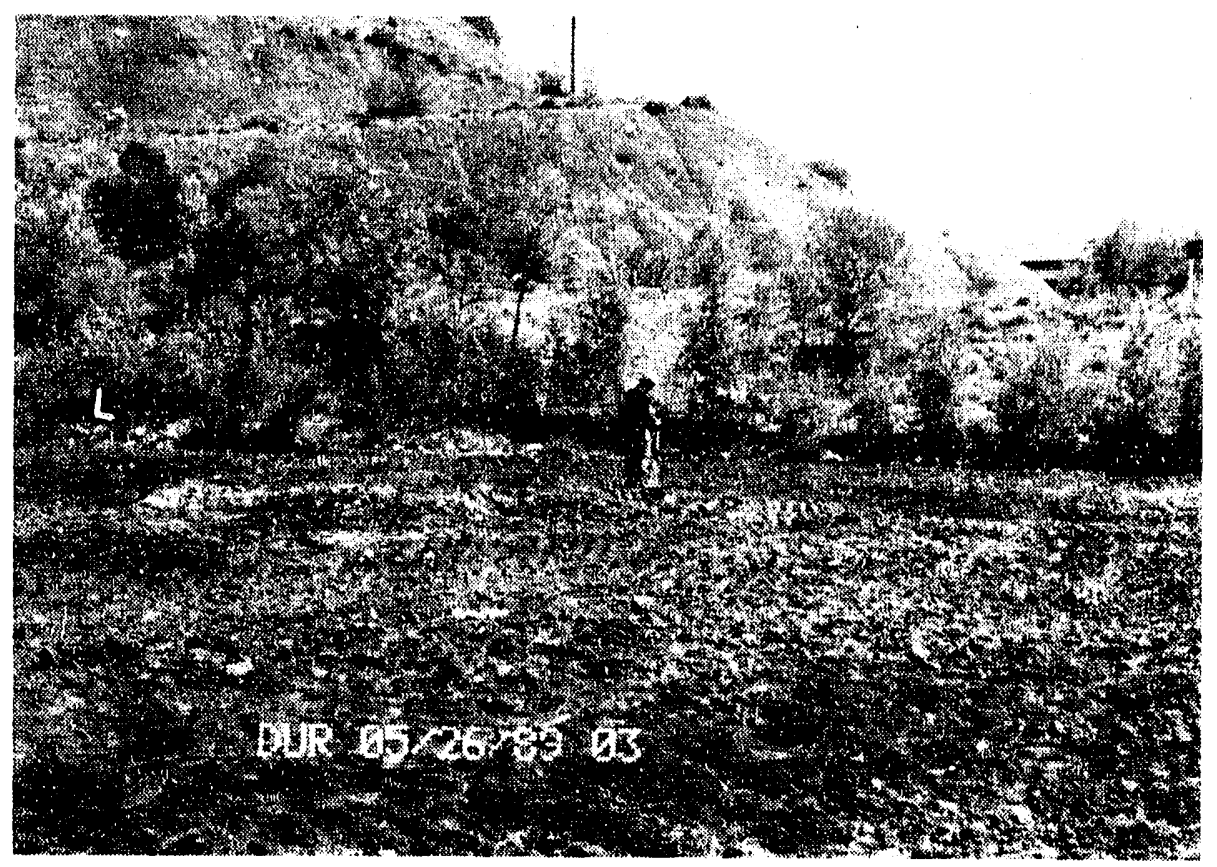

Staking sampling locations iur to verification of the clean area at the Durango, Co, processing site. 


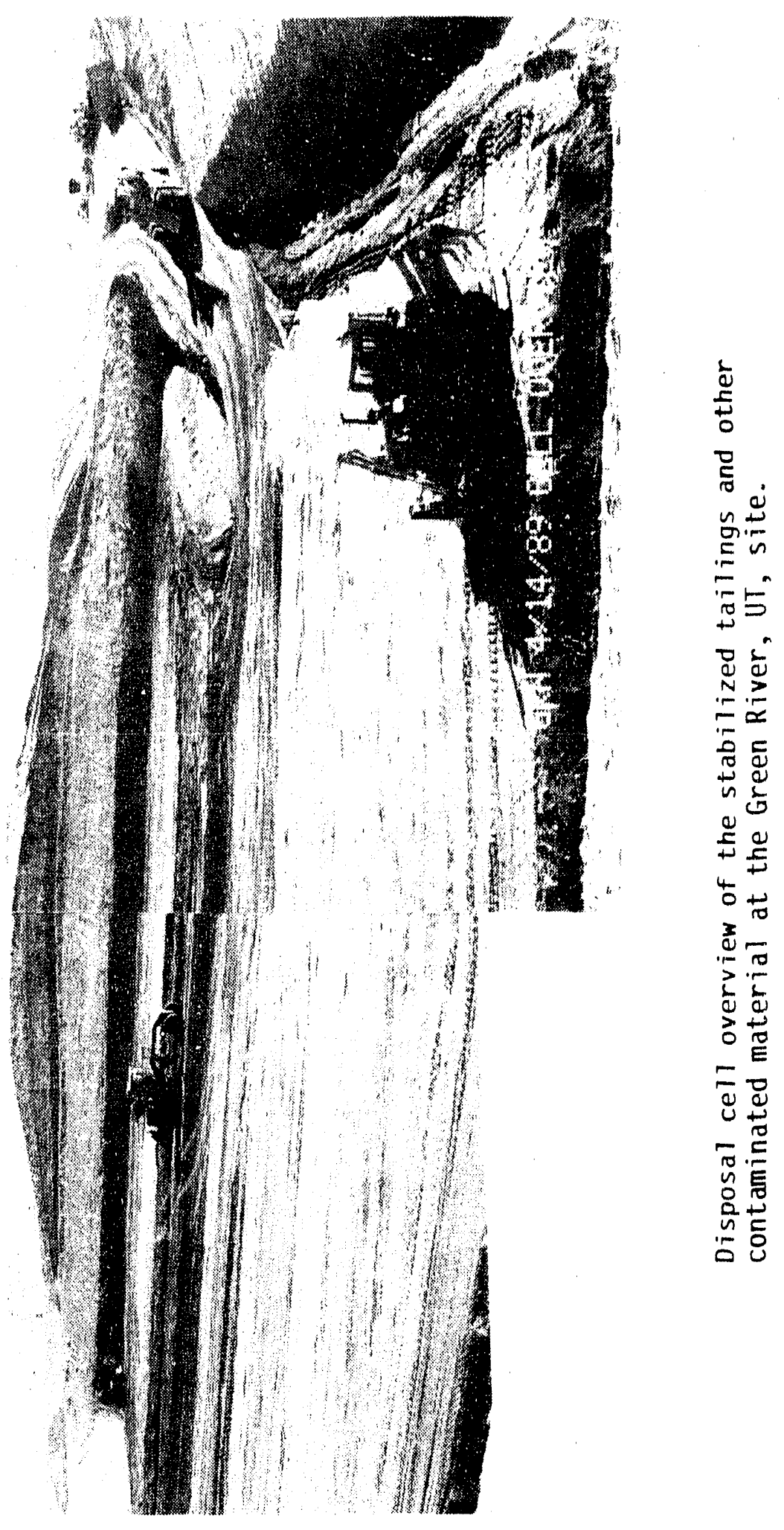




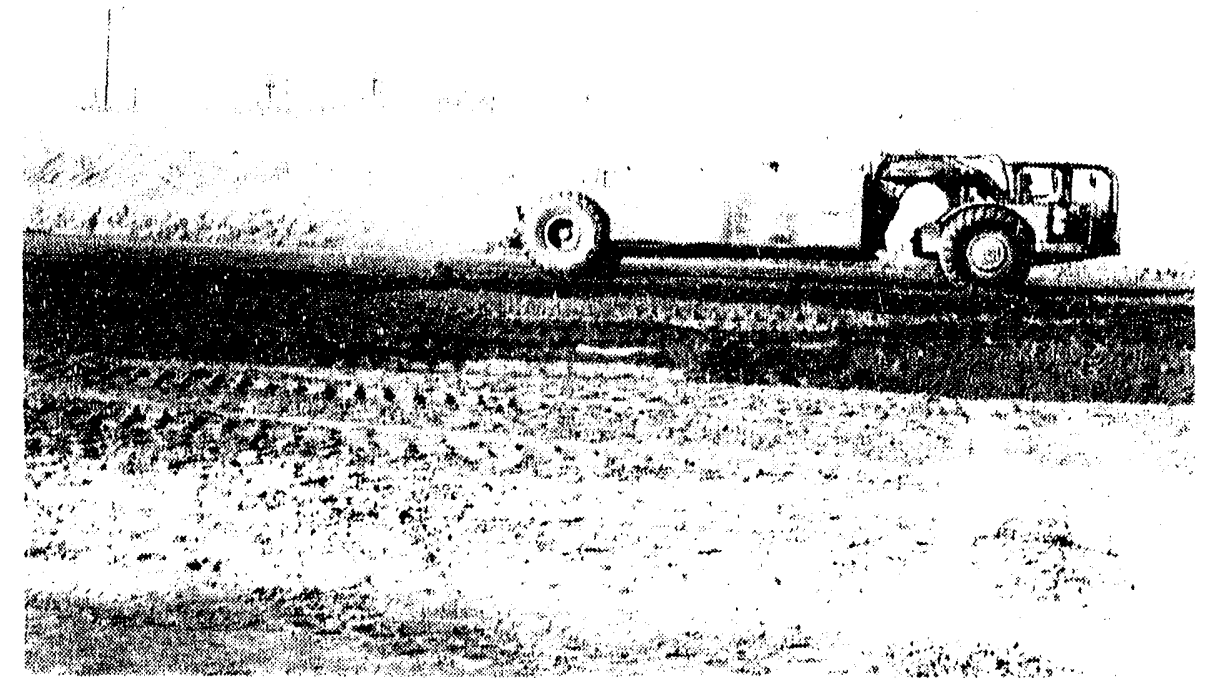

Dust control at the Green River, UT, site as moisture is applied to the cell.

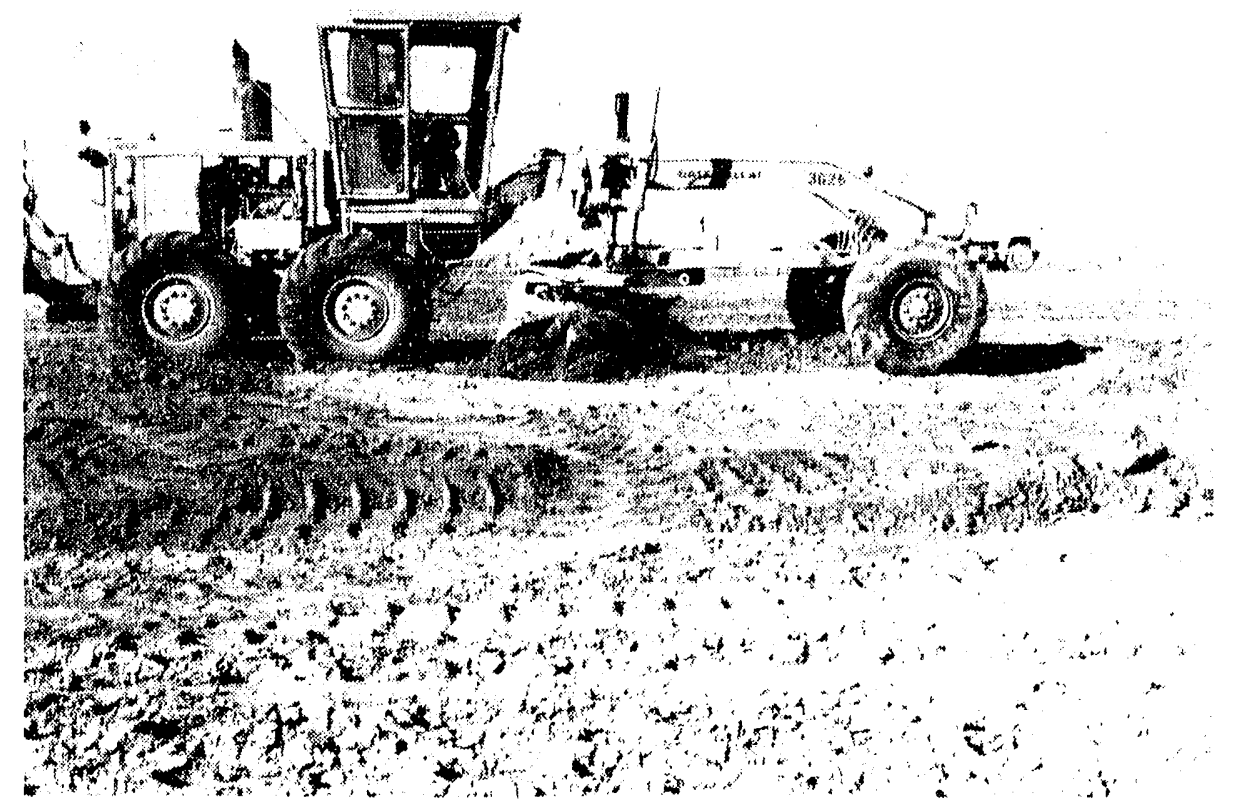

Processing and placement of windblown and other contaminated material at the Green River, UT, site. 


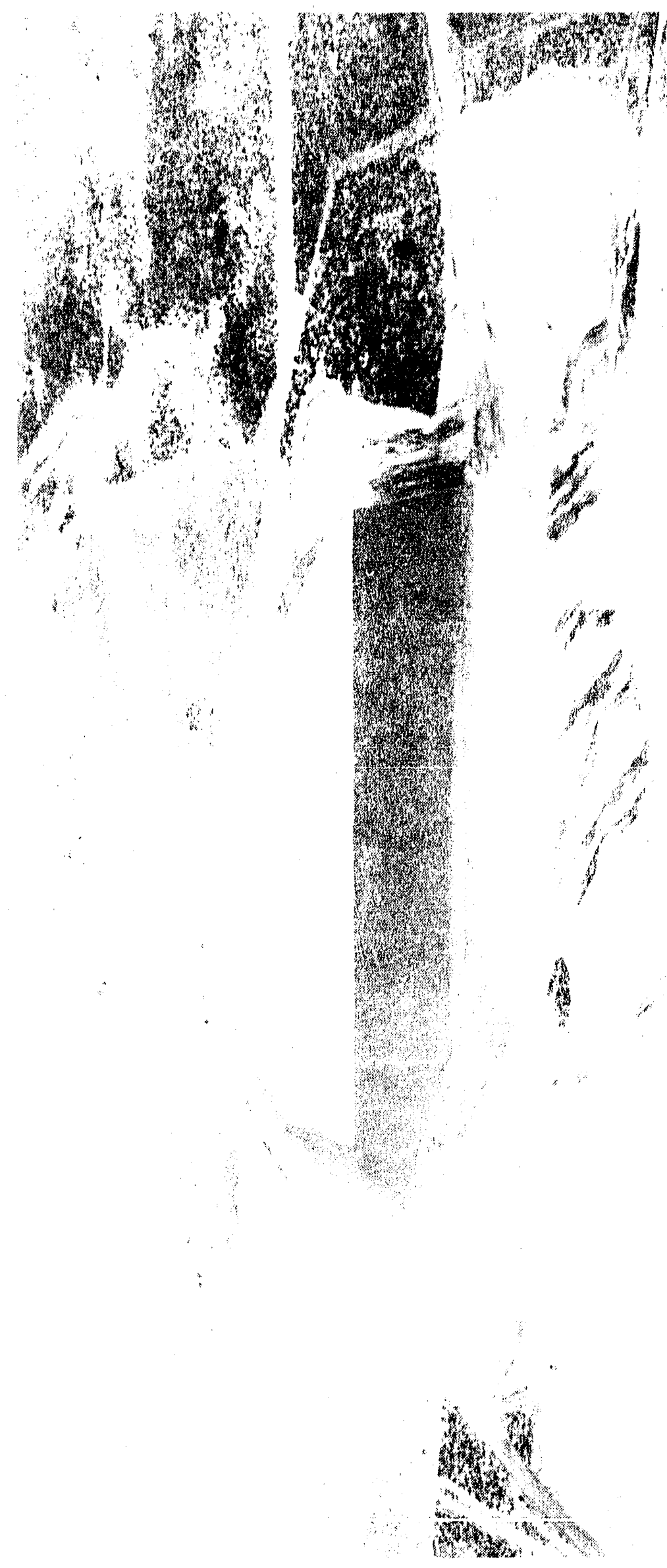

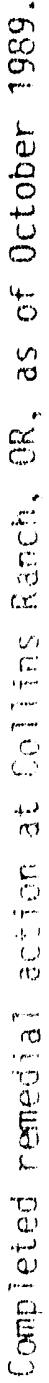




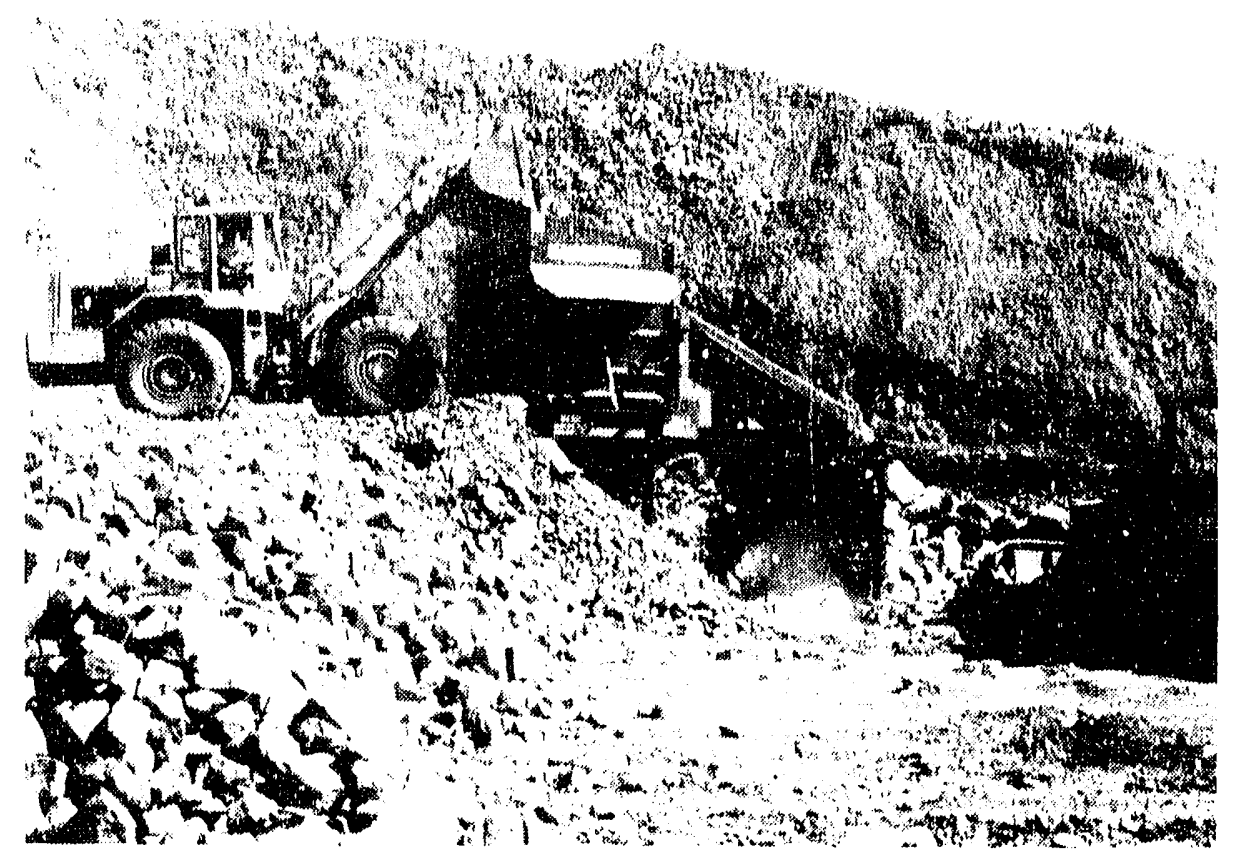

A motorized grizzley, located at the Shear's quarry, is used to produce erosion protection rock (RIPRAP) for the covering of the Lakeview, OR, tailings.

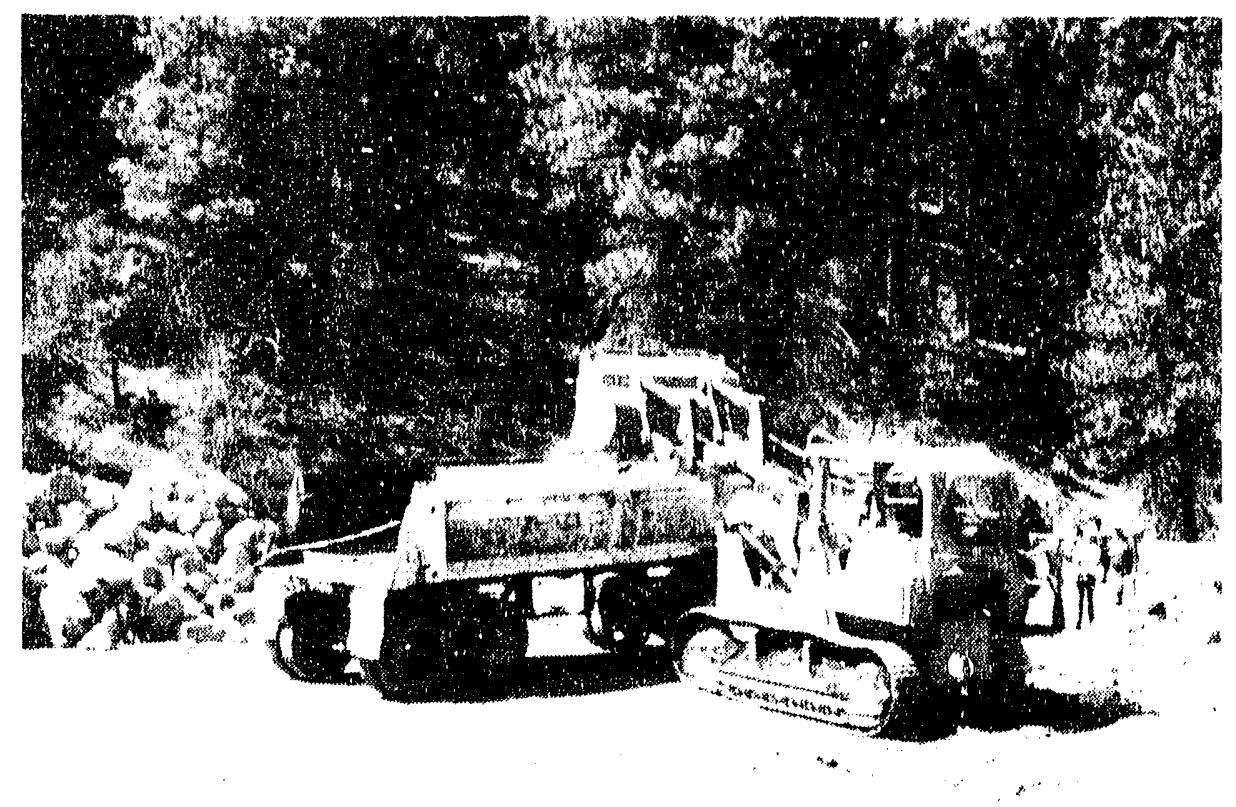

Type C RIPRAP is being loaded at Shear's quarry to be used aj covering for the lakeview Lailings located at the Collins Ranch, OR, area. 


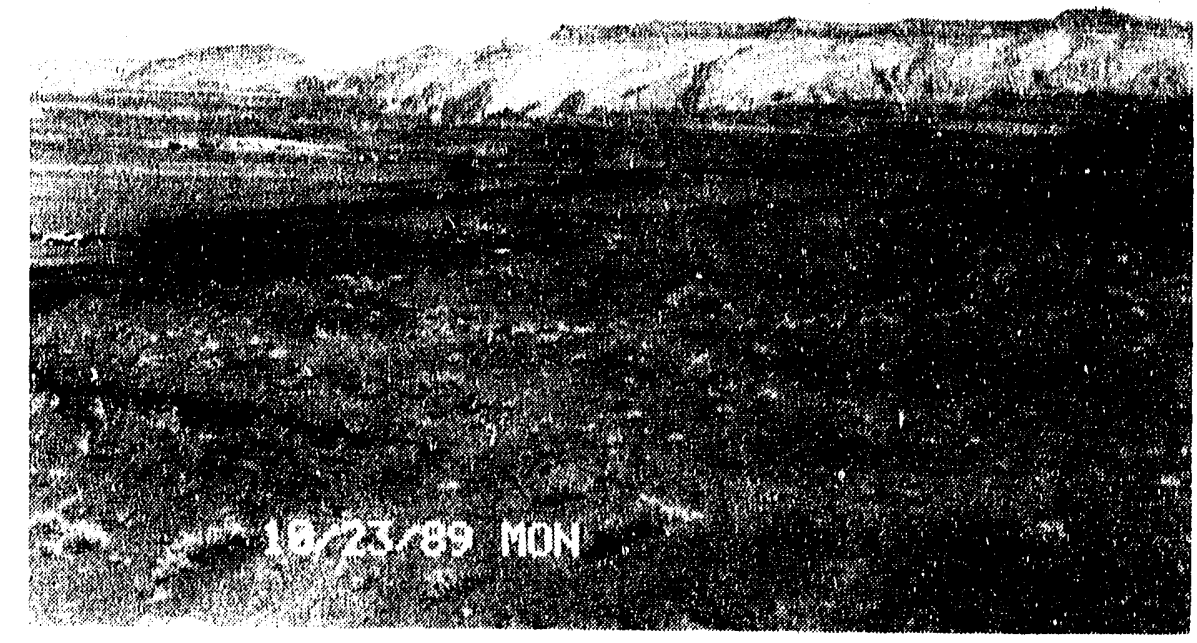

East side view of disposal cell at the Mexican Hat, UT, site.

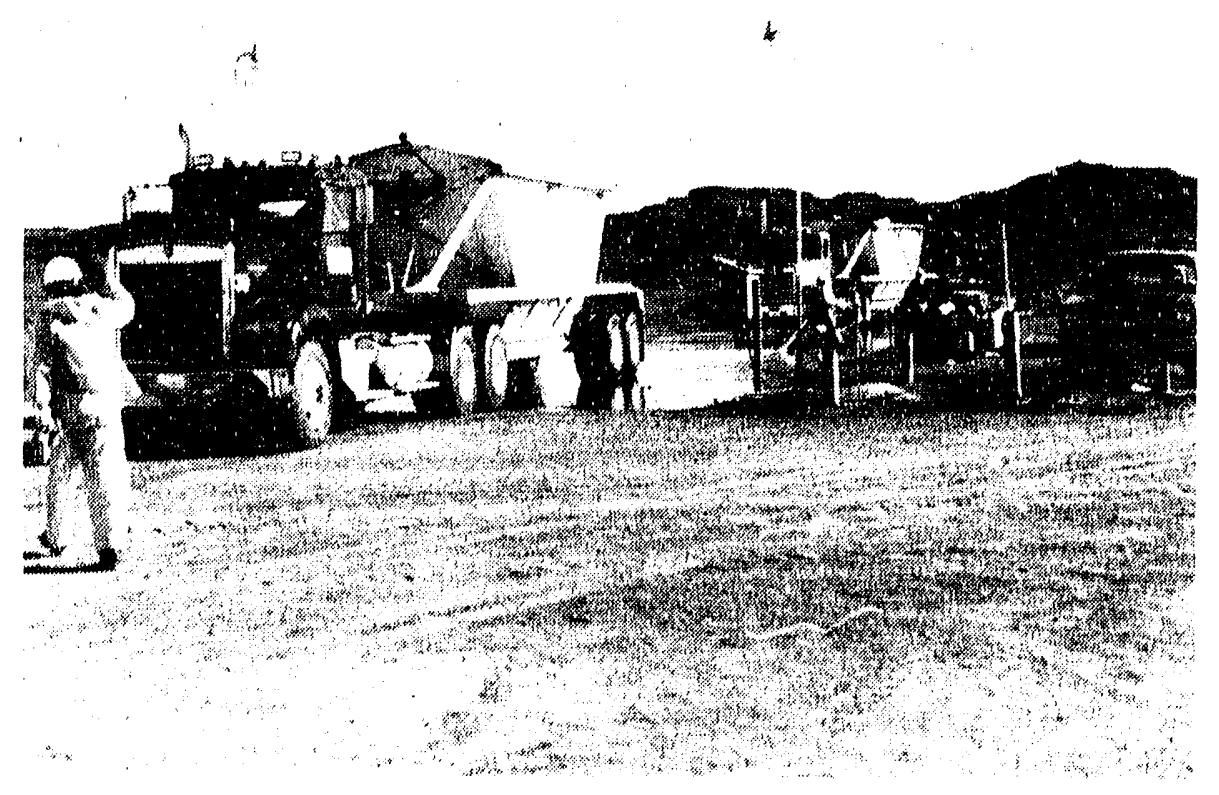

Decontamination of trucks at the Mexican Hat, UT, site after haul of tailings from the Monument Valley, Az, Processing site. 


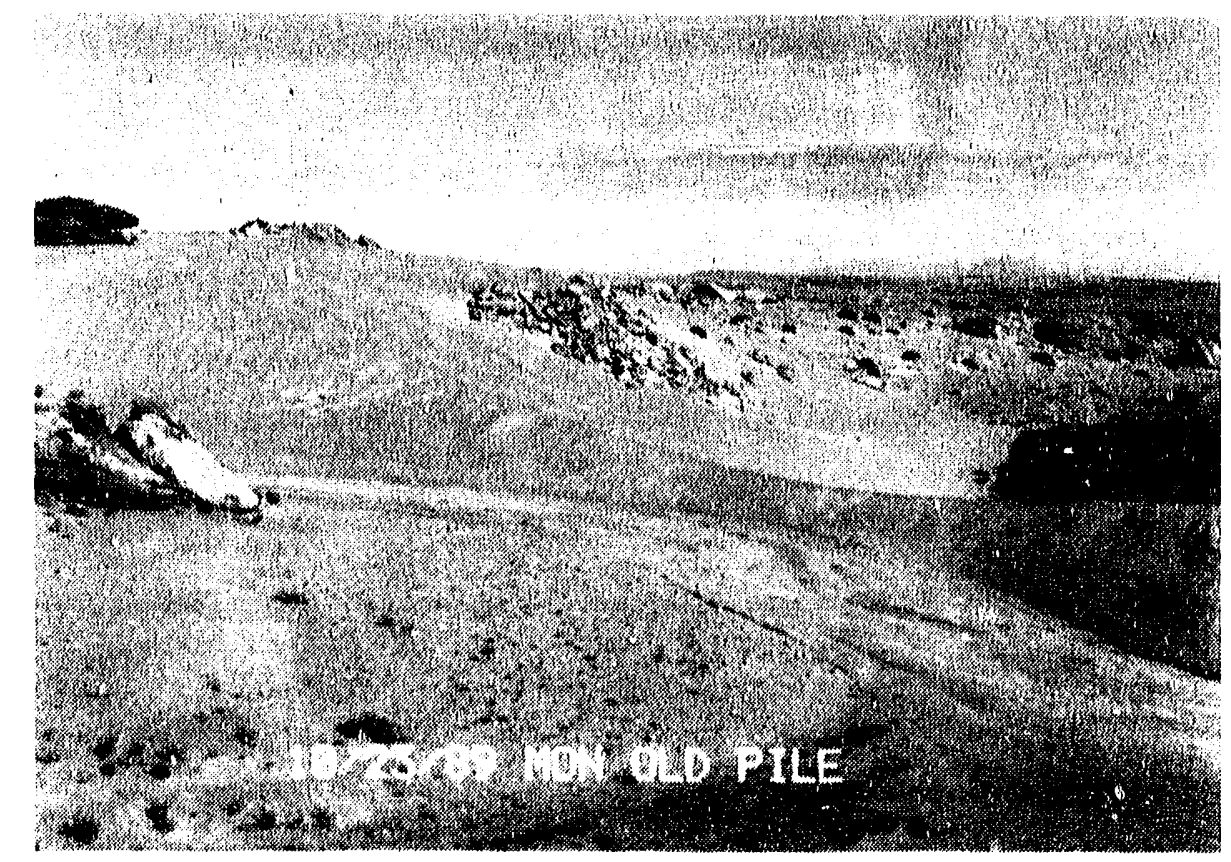

01d tailings pile at the Monument Valley, AZ, processing site.

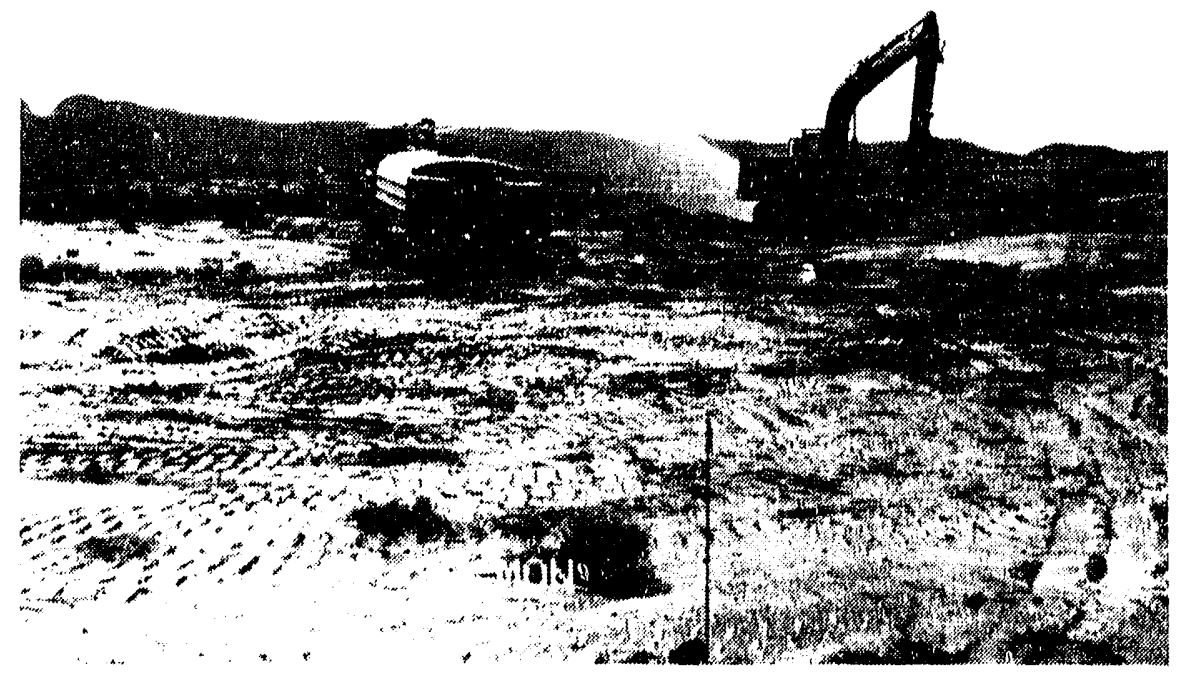

Dust control activities at the southwest side of the processing site at Monument Valley, AZ. 


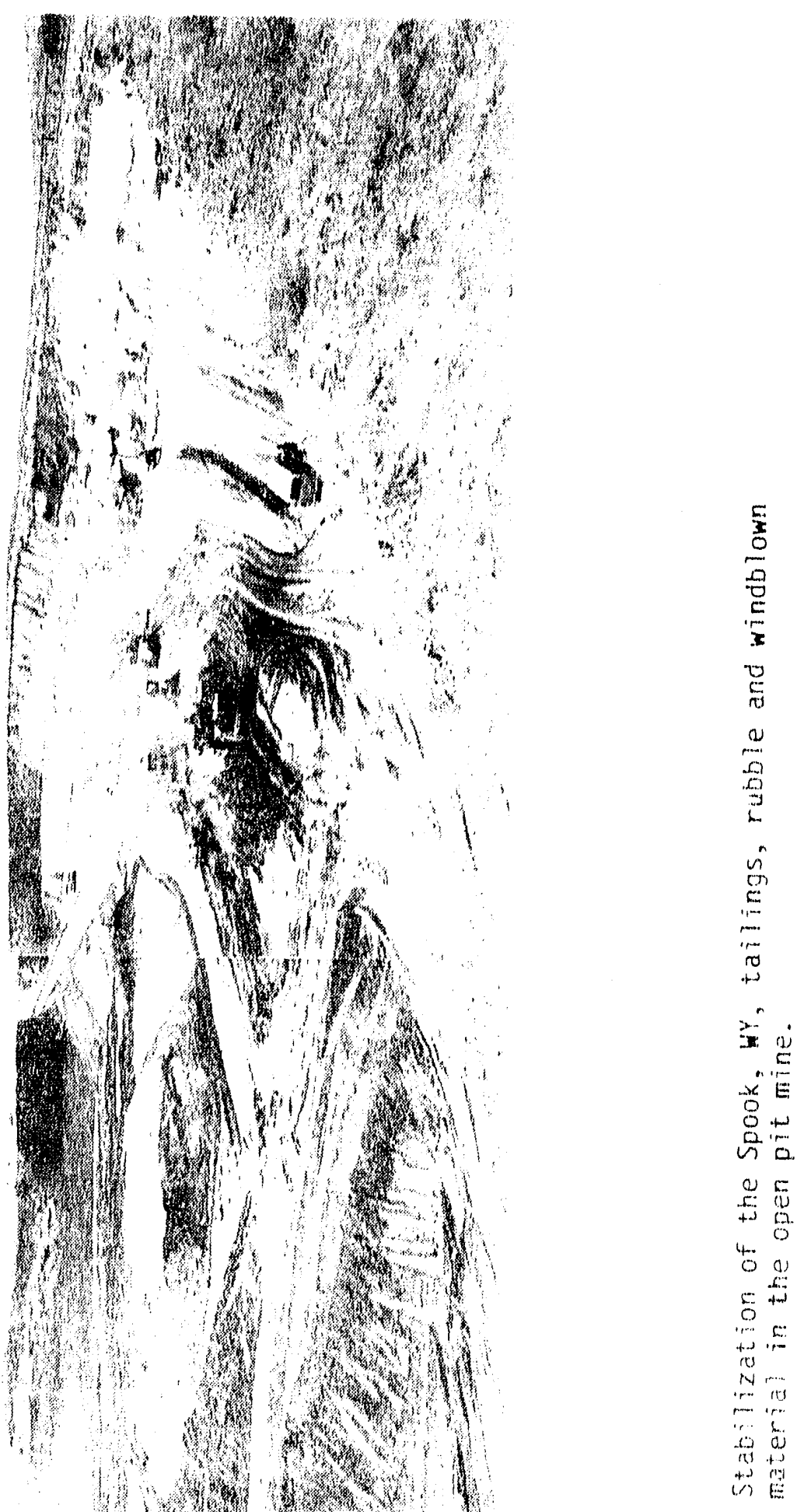




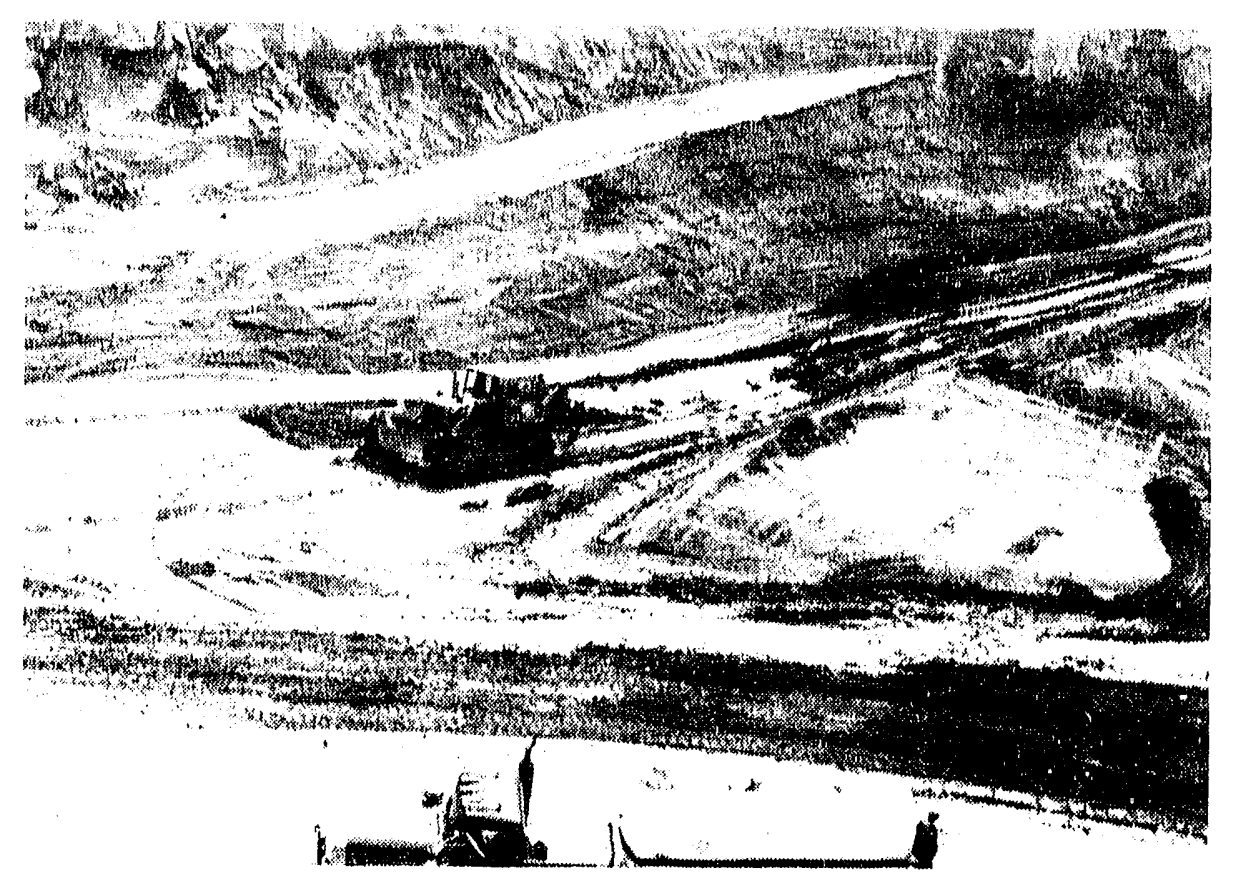

Wet Tailings removal from the north end of the open pit at the Spook, WY, site.

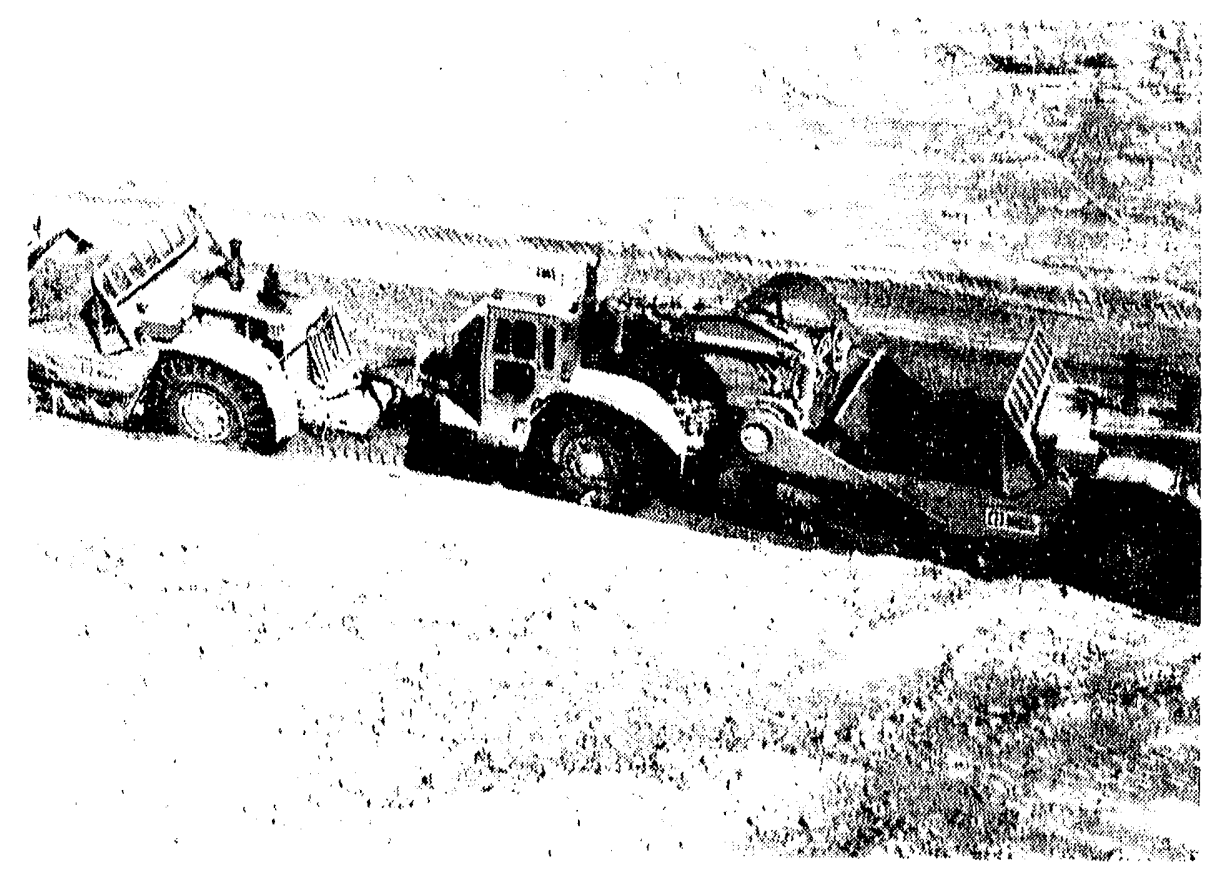

Scrapers removing saturated tailings from the Spook, WY, site to be placed in the open pit. mine. 


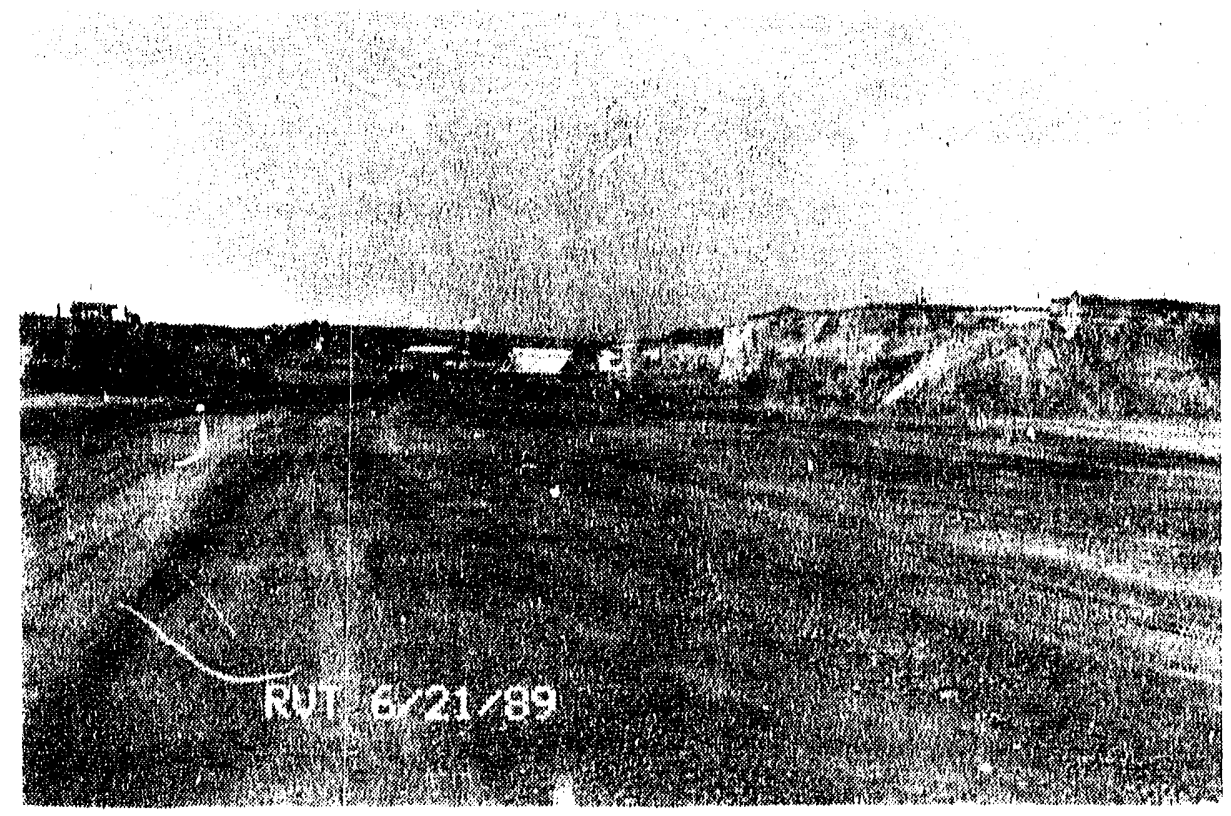

Tailings excavation from the pile at the Riverton, WY, processing site slated for the relocation to the Gas Hills, WY, disposal site.

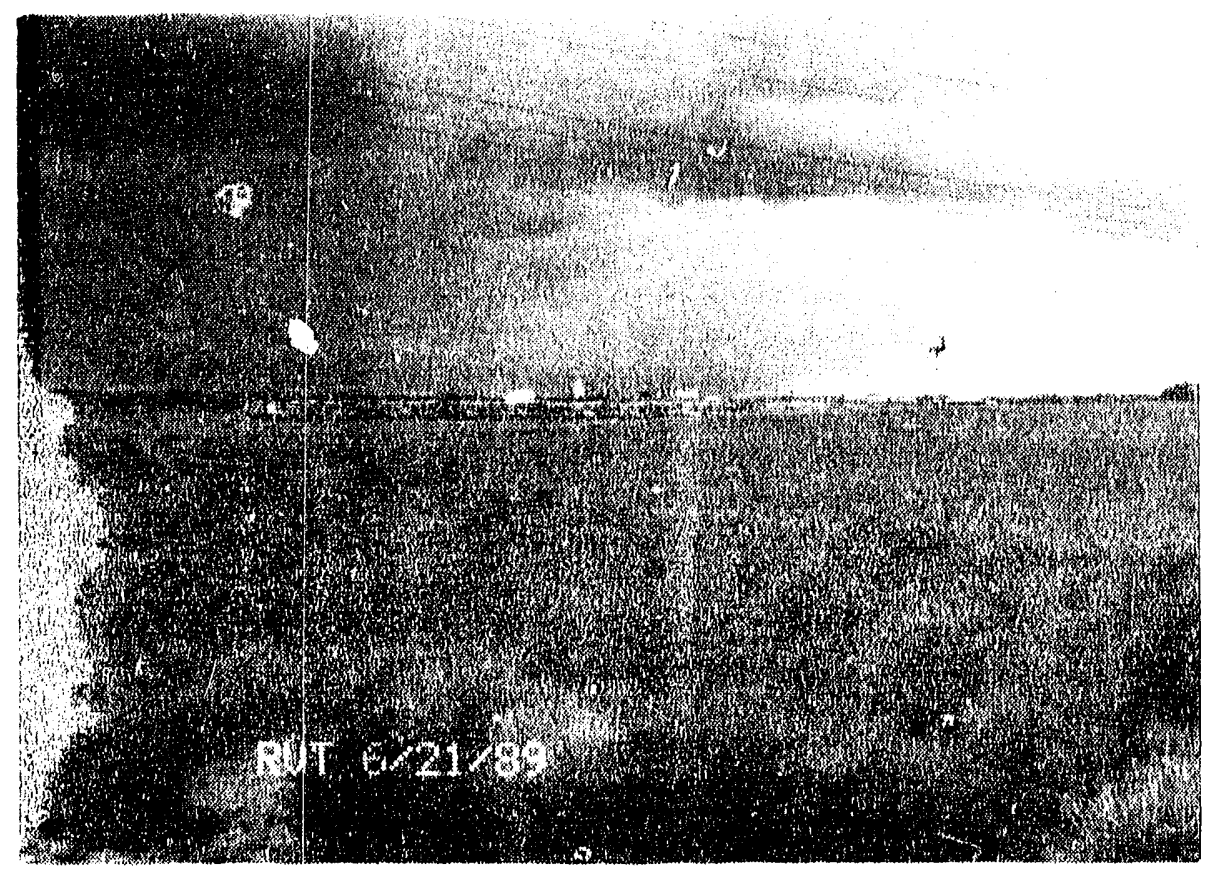

Freshly planted barley field, Vicinity Property, and processing site following remedial action at the Riverton, WY, site. 

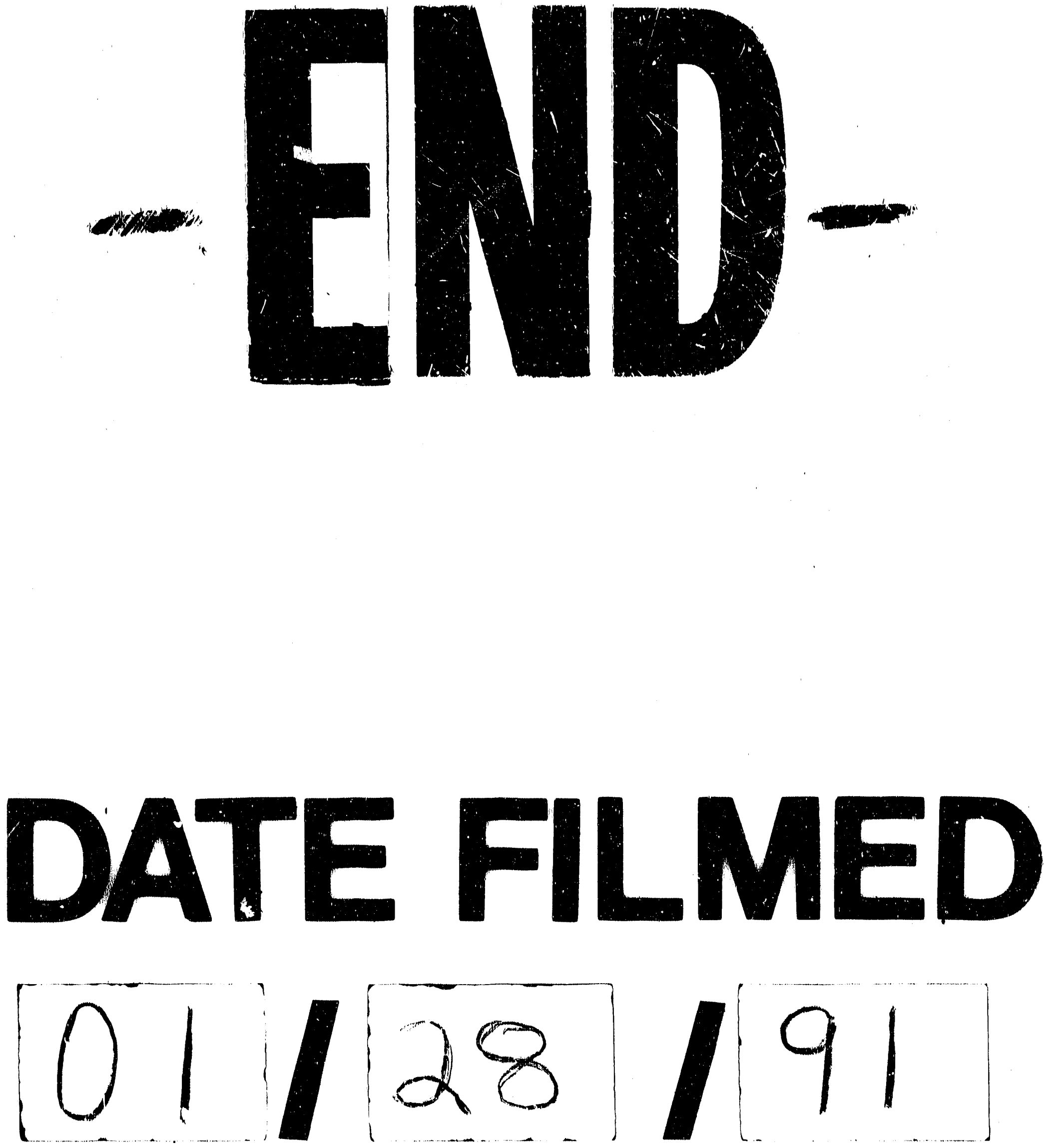